Article

\title{
Synthesis, Crystal Structure, Electrochemistry and Electro-Catalytic Properties of the Manganese-Containing Polyoxotungstate, $\left[\left(\mathrm{Mn}\left(\mathrm{H}_{2} \mathrm{O}\right)_{3}\right)_{2}\left(\mathrm{H}_{2} \mathrm{~W}_{12} \mathrm{O}_{42}\right)\right]^{6-}$
}

\author{
Anne-Lucie Teillout ${ }^{1}$, Pedro de Oliveira ${ }^{1}$, Jérôme Marrot ${ }^{2}$, Robertha C. Howell ${ }^{3,+}{ }^{\dagger}$, Neus Vilà ${ }^{4}$, \\ Alain Walcarius ${ }^{4}$ and Israël M. Mbomekallé ${ }^{1, *} \mathbb{B}$ \\ 1 Equipe d'Electrochimie et de Photo-électrochimie, Laboratoire de Chimie Physique, Univ Paris Sud, \\ UMR 8000 CNRS, Université Paris-Saclay, F-91405 Orsay, France; anne-lucie.teillout@u-psud.fr (A.-L.T.); \\ pedro.deoliveira@u-psud.fr (P.d.O.) \\ 2 Institut Lavoisier de Versailles, Université de Versailles St. Quentin, UMR 8180 CNRS, \\ Université Paris-Saclay, F-78035 Versailles, France; jerome.marrot@uvsq.fr \\ 3 Oregon State University, Department of Nuclear Engineering and Radiation Health Physics, Corvallis, \\ OR 97331, USA; robertha.howell@gmail.com \\ 4 Laboratoire de Chimie Physique et Microbiologie pour les Matériaux et l'Environnement, UMR 7564 CNRS, \\ Université de Lorraine, 405 rue de Vandoeuvre, F-54600 Villers-lès-Nancy, France; \\ neus.vila@univ-lorraine.fr (N.V.); alain.walcarius@univ-lorraine.fr (A.W.) \\ * Correspondence: israel.mbomekalle@u-psud.fr; Tel.: +33-169-154-159 \\ † Current address: Intel Corporation, 4500 S Dobson Road, Chandler, AZ 85248, USA.
}

Received: 12 November 2018; Accepted: 27 January 2019; Published: 2 February 2019

\begin{abstract}
We present the synthesis and structural characterization of the manganese-containing polyoxotungstate, $\left[\left(\mathrm{Mn}\left(\mathrm{H}_{2} \mathrm{O}\right)_{3}\right)_{2}\left(\mathrm{H}_{2} \mathrm{~W}_{12} \mathrm{O}_{42}\right)\right]^{6-}(\mathbf{1})$, obtained by reaction of $\mathrm{MnCl}_{2}$ with six equivalents of $\mathrm{Na}_{2} \mathrm{WO}_{4}$ in the presence of $\mathrm{Zn}\left(\mathrm{CH}_{3} \mathrm{COO}\right)_{2}$ in acetate medium ( $\mathrm{pH}$ 4.7). This has been assessed by various techniques (FTIR, TGA, UV-Visible, XPS, elemental analysis, single crystal $\mathrm{X}$-ray and electrochemistry). Single-crystal X-ray analyses showed that, in the solid state, $\mathbf{1}$ forms a 2-D network in which $\left[\mathrm{H}_{2} \mathrm{~W}_{12} \mathrm{O}_{42}\right]^{10-}$ fragments are linked in pairs via $\mathrm{Mn}^{2+}$ ions, leading to linear chains of the form $\left[\left(\mathrm{Mn}\left(\mathrm{H}_{2} \mathrm{O}\right)_{3}\right)_{2}\left(\mathrm{H}_{2} \mathrm{~W}_{12} \mathrm{O}_{42}\right)\right]_{n}{ }^{6 n-}$. The connection between chains occurs also via $\mathrm{Mn}^{2+}$ ions which bind $\left[\mathrm{H}_{2} \mathrm{~W}_{12} \mathrm{O}_{42}\right]^{10-}$ fragments belonging to two adjacent chains, forming an infinite 2-D network. A complete electrochemical study was done in aqueous solution where $\mathbf{1}$ is stable in the $\mathrm{pH}$ range 1 to 6 . This complex undergoes multiple electron-transfer processes that lead to the electro-generation of manganese high oxidation state species that catalyse water electro-oxidation. $\mathbf{1}$ is also effective in the electro-catalytic reduction of nitrite and dioxygen.
\end{abstract}

Keywords: polyoxometalates; manganese; X-ray structure; XPS; electrochemistry; electro-catalysis; WOC; $\mathrm{O}_{2}$ reduction; $\mathrm{NO}_{x}$ reduction

\section{Introduction}

Polyoxometalates (POMs) constitute a class of inorganic materials whose properties may be modulated upon inserting specifically chosen chemical elements in their scaffold. This results in a myriad of proved and potential applications in several domains such as materials sciences, magnetism, catalysis and electro-catalysis, photochemistry and medicine [1-3]. However, the formation of these anionic structures is more the result of the evolution of chemical equilibria not always mastered than that of rational chemical synthesis protocols [4-9]. Since more than a decade now, we have been contributing to understand and develop efficient, rational and new synthetic routes for POMs that are 
likely to play a major role in catalysis and in electro-catalysis [10-17]. We are particularly interested in sandwich-type, tungstic POMs of the DAWSON family, in which two $\left[\mathrm{X}_{2} \mathrm{~W}_{15} \mathrm{O}_{56}\right]^{12-}$ (with $\mathrm{X}=\mathrm{As}$ or $\mathrm{P}$ ) fragments coordinate an equatorial metallic cluster $\left[\mathrm{M}_{x} \mathrm{O}_{y}\right]$ (with $\mathrm{M}=\mathrm{Mn}, \mathrm{Fe}, \mathrm{Co}, \mathrm{Ni}, \mathrm{Cu}$ or $\mathrm{Zn}$ ) [18-22]. The number of metal centres in the cluster may vary from 2 to 4 (or even higher in some cases) and include up to two different elements [23-27]. We have established multi-step synthesis protocols allowing to modulate the chemical composition of the equatorial cluster, which open the way for the targeted synthesis of a large set of new compounds [14,28-31]. From this perspective, the compounds of the Keggin family [32], which have a higher diversity both in composition and in lacunary structures, are even more interesting. In fact, at least four different types of tungstic Keggin fragments may be cited which are prone to the formation of sandwich-type structures. They formally result from the partial decay of the parent compound $\left[\mathrm{XW}_{12} \mathrm{O}_{40}\right]^{n-}$, leading to the formation of the following lacunary entities: $\left[\mathrm{XW}_{8} \mathrm{O}_{31}\right]^{n-},\left[\mathrm{XW}_{9} \mathrm{O}_{33}\right]^{n-},\left[\mathrm{XW}_{9} \mathrm{O}_{34}\right]^{n-}$ or $\left[\mathrm{XW}_{10} \mathrm{O}_{36}\right]^{n-}($ with $\mathrm{X}=\mathrm{B}, \mathrm{Al}$, $\mathrm{Si}, \mathrm{P}, \mathrm{Zn}, \mathrm{Ga}, \mathrm{As}, \ldots$ ) [4]. In practice, these lacunary compounds are more often the products of direct syntheses other than the outcome of controlled degradation processes of a parent Keggin structure. In any case, the number of possible combinations, if we ever arrive at fully understanding and mastering the formation of these compounds, seems unlimited. The same is true for their potential applications.

In order to stay in the context of our research, which goes from unravelling the POM formation mechanisms up to the employment of their properties in diverse applications, we have decided to start our study with manganese-containing POMs. Indeed, we are interested in manganese-containing POMs because they are known to exhibit significant activity in many oxidative catalytic or electro-catalytic processes upon the formation of highly reactive oxo-Mn(V) species [33-53]. Several studies seem to confirm that in the case of the electro-catalytic oxidation of water, for example in the presence of POMs containing cobalt or manganese centres, the electro-active species are cobalt or manganese oxides which are deposited as films on the surface of the working electrode as a result of a partial decomposition of the POM [54-59]. It seems pertinent to highlight the contribution and the importance of the species in solution, which is the non-decomposed POM, in the observed electro-catalytic process, which has already been proposed in previous studies [60-64]. It is therefore important to prepare new POM molecules that contain several manganese centres that are easy to oxidise and remain stable in solution.

The objective of this study is to prepare a manganese-containing polyoxometalate that combines two characteristics: (1) a large number of $\mathrm{Mn}^{2+}$ centres; (2) a high charge density value (ratio of the formal charge of the POM with respect to its volume). The idea is to lower as much as possible the apparent redox potential values for the oxidation of these $\mathrm{Mn}^{2+}$ centres, thus reaching more easily their higher oxidation states $\mathrm{Mn}^{4+}$ and $\mathrm{Mn}^{5+}$. Towards this goal, we attempted to prepare a Keggin Sandwich-type complex, $\left[\mathrm{Mn}_{2}\left(\mathrm{MnOH}_{2}\right)_{2}\left(\mathrm{ZnW}_{9} \mathrm{O}_{34}\right)_{2}\right]^{16-}$, comprising two $\left[\mathrm{ZnW}_{9} \mathrm{O}_{34}\right]^{12-}$ moieties and four $\mathrm{Mn}^{2+}$ centres. Instead, we obtained the complex $\left[\left(\mathrm{Mn}\left(\mathrm{H}_{2} \mathrm{O}\right)_{3}\right)_{2}\left(\mathrm{H}_{2} \mathrm{~W}_{12} \mathrm{O}_{42}\right)\right]^{6-}$, 1, which crystallises in the solid state as a two-dimension polymer that can be formulated as $\left[\left(\mathrm{Mn}\left(\mathrm{H}_{2} \mathrm{O}\right)_{3}\right)_{2}\left(\mathrm{H}_{2} \mathrm{~W}_{12} \mathrm{O}_{42}\right)\right]_{n}{ }^{6 n-}$. In solution, the monomer species, $\left[\left(\mathrm{Mn}\left(\mathrm{H}_{2} \mathrm{O}\right)_{3}\right)_{2}\left(\mathrm{H}_{2} \mathrm{~W}_{12} \mathrm{O}_{42}\right)\right]^{6-}$, has roughly the same size and the same formal electrical charge as other plenary Keggin moieties, $\left[\mathrm{XW}_{12} \mathrm{O}_{40}\right]^{n-}\left(\mathrm{X}=\mathrm{Al}, \mathrm{B}, \mathrm{Co}, \mathrm{Zn}, \mathrm{H}_{2}, \ldots\right)$ [4] but possesses at least two extra relevant electrochemical properties with respect to the latter: (1) the tungstic scaffold is easier to reduce in the case of the new compound $\left[\left(\mathrm{Mn}\left(\mathrm{H}_{2} \mathrm{O}\right)_{3}\right)_{2}\left(\mathrm{H}_{2} \mathrm{~W}_{12} \mathrm{O}_{42}\right)\right]^{6-}$, rendering the electro-catalytic reduction of nitrite and dioxygen more favourable; (2) the two $\mathrm{Mn}^{2+}$ centres bound to its structure are easily accessible and their oxidation may be carried out at not so high potentials. This oxidation is concomitant with the formation of metal oxide deposits which favour the electro-catalytic oxidation of water, as demonstrated by previous studies, some of them being more recent than others $[54-59,63,65,66]$. 


\section{Results and Discussion}

\subsection{Synthesis and Structure}

As stated in the introduction and in the experimental section, compound $\mathbf{1}$ was obtained when attempting to prepare the sandwich-type complex $\left[\mathrm{Mn}_{2}\left(\mathrm{MnOH}_{2}\right)_{2}\left(\mathrm{ZnW}_{9} \mathrm{O}_{34}\right)_{2}\right]^{16-}$, starting from $\mathrm{Na}_{2} \mathrm{WO}_{4} \cdot 2 \mathrm{H}_{2} \mathrm{O}, \mathrm{Zn}\left(\mathrm{CH}_{3} \mathrm{COO}\right)_{2} \cdot 2 \mathrm{H}_{2} \mathrm{O}$ and $\mathrm{MnCl}_{2} \cdot 4 \mathrm{H}_{2} \mathrm{O}$ in acetate buffer. As reported in other studies, the reaction of tungstate salts with elements such as $\mathrm{Al}, \mathrm{Bi}, \mathrm{Co}, \mathrm{Fe}$ or $\mathrm{Mn}$, in the absence of $\mathrm{Zn}$, sometimes leads to the formation of paradodecatungstate units, $\left[\mathrm{H}_{2} \mathrm{~W}_{12} \mathrm{O}_{42}\right]^{10-}$, that are, in a few cases, linked together by one or more " $\mathrm{d}$ " metal ions to form extended networks [67-73]. Similarly, other attempts were done with $\mathrm{Al}^{3+}, \mathrm{Co}^{2+}$ or $\mathrm{Fe}^{3+}$ instead of $\mathrm{Zn}^{2+}$ but we failed to obtained the corresponding analogues of the expected compounds, $\left[\mathrm{Mn}_{2}\left(\mathrm{MnOH}_{2}\right)_{2}\left(\mathrm{MW}_{9} \mathrm{O}_{34}\right)_{2}\right]^{n-}$, with $\mathrm{M}=\mathrm{Al}, \mathrm{Co}$ or Fe. This method was already successfully used in the past in the case of the synthesis of the species $\left[\mathrm{Fe}_{2}\left(\mathrm{CuOH}_{2}\right)_{2}\left(\mathrm{FeW}_{9} \mathrm{O}_{34}\right)_{2}\right]^{10}$, for example [74]. In our case, the presence of $\mathrm{Zn}^{2+}$ ions seems to catalyse the formation of $\left[\mathrm{H}_{2} \mathrm{~W}_{12} \mathrm{O}_{42}\right]^{10-}$ fragments that are connected together by two $\mathrm{Mn}^{2+}$ ions. Elemental analysis did not reveal any traces of zinc in the final product, which was then formulated as the mixed sodium and potassium salt $\mathrm{K}_{2} \mathrm{Na}_{4}\left[\left(\mathrm{Mn}\left(\mathrm{H}_{2} \mathrm{O}\right)_{3}\right)_{2}\left(\mathrm{H}_{2} \mathrm{~W}_{12} \mathrm{O}_{42}\right)\right] \cdot 28 \mathrm{H}_{2} \mathrm{O}$.

In the solid state, $\mathbf{1}$ can be viewed as an extended 2-D network consisting of $\left[\mathrm{H}_{2} \mathrm{~W}_{12} \mathrm{O}_{42}\right]^{10-}\left(\mathrm{W}_{12}\right)$ moieties linked together by $\mathrm{Mn}^{2+}, \mathrm{K}^{+}$and $\mathrm{Na}^{+}$ions (Figure 1a). The $\mathrm{W}_{12}$ entity is composed of four trimetallic subunits, $W_{3}$, which are equivalent in pairs. The $W_{3}$ subunits located at both ends of the $\mathrm{W}_{12}$ moiety (blue balls on Figure $1 \mathrm{~b}-\mathrm{d}$ ) form "cap-type" $\mathrm{W}$, while the $\mathrm{W}_{3}$ located on the meridional region of the $\mathrm{W}_{12}$ moiety (blue polyhedrons on Figure $1 \mathrm{~b}-\mathrm{d}$ ), form a more open "belt-type" region with the tungsten species possessing 2 terminal oxygen atoms each. Terminal $\mathrm{W}-\mathrm{O}$ distances vary slightly from the "cap" to the "belt," with the "cap" W-O being comprised between 1.741(3) and 1.747(2), while the "belt" W-O lengths are comprised between 1.719(3) and 1.753(3) A. Each dodecatungstate, $\mathrm{W}_{12}$, unit is coordinated to $4 \mathrm{Mn}^{2+}$ ions that link the $\mathrm{W}_{12}$ units into chains. The $\mathrm{Mn}^{2+}$ ion is in a distorted octahedral environment, coordinated to two "cap-type" terminal oxygens in one $\mathrm{W}_{12}$ unit and one "cap-like" oxygen in the adjoining $\mathrm{W}_{12}$ unit along with $3 \mathrm{H}_{2} \mathrm{O}$ molecules. Mn-O bond lengths show little variation, with bridging Mn-O-W bond lengths ranging from 2.163(3) to 2.180(2) $\AA$ and $\mathrm{Mn}-\mathrm{OH}_{2}$ bond lengths being 2.163(2) to 2.183(3) $\AA$ (Table 1). There are three unique six-coordinate sodium ions that organize the chains into a 2-dimensional structure. The first sodium ion is coordinated to terminal oxygens on adjacent chains in the "belt" of the $\mathrm{W}_{12}$ unit along with four $\mathrm{H}_{2} \mathrm{O}$ molecules. The other two sodium ions are six-coordinated to $\mathrm{H}_{2} \mathrm{O}$ molecules. The structure of $\mathbf{1}$ as presented above is, at first sight, very similar to that described by Ganglin Xue et al. [73] but there is a major difference between the two compounds. In the present case, the junction between the 1-D chains $\left[\left(\mathrm{Mn}\left(\mathrm{H}_{2} \mathrm{O}\right)_{3}\right)_{2}\left(\mathrm{H}_{2} \mathrm{~W}_{12} \mathrm{O}_{42}\right)\right]_{n}{ }^{6 n-}$ is formed thanks to $\mathrm{Na}^{+}$ions via $\mathrm{Na}-\mathrm{O}-\mathrm{W}$ bridging bonds (Figure 1a). In the structure described by Ganglin Xue et al., the chains are linked to each other $\mathrm{Mn}^{2+}$ ions via Mn-O-W bridging bonds.

Table 1. Bond lengths ( $\mathrm{\AA}$ ) and angles (deg.) for $\mathbf{1}$.

\begin{tabular}{cccccc}
\hline Mn1-O22 & $2.163(2)$ & O7-Mn1-O11 & $168.12(9)$ & O22-Mn1-O16 & $170.81(9)$ \\
Mn1-O23 & $2.176(3)$ & O7-Mn1-O16 & $87.04(10)$ & O22-Mn1-O23 & $88.48(9)$ \\
Mn1-O24 & $2.183(3)$ & O7-Mn1-O22 & $87.13(10)$ & O22-Mn1-O24 & $86.49(10)$ \\
Mn1-O7 & $2.163(3)$ & O7-Mn1-O24 & $96.89(10)$ & O23-Mn1-O24 & $173.02(10)$ \\
Mn1-O11 & $2.177(3)$ & O7-Mn1-O23 & $87.67(10)$ & O23-Mn1-O11 & $80.56(10)$ \\
Mn1-O16 & $2.180(2)$ & O11-Mn1-O16 & $93.04(9)$ & O23-Mn1-O16 & $98.38(9)$ \\
W2-O7 & $1.746(3)$ & O11-Mn1-O24 & $94.97(11)$ & & \\
W3-O11 & $1.779(2)$ & O16-Mn1-O24 & $87.16(9)$ & & \\
W4-O16 & $1.793(2)$ & O22-Mn1-O11 & $94.12(10)$ & & \\
\hline
\end{tabular}




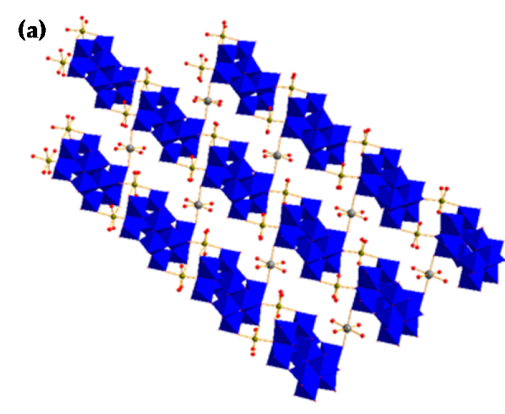

(d) 9
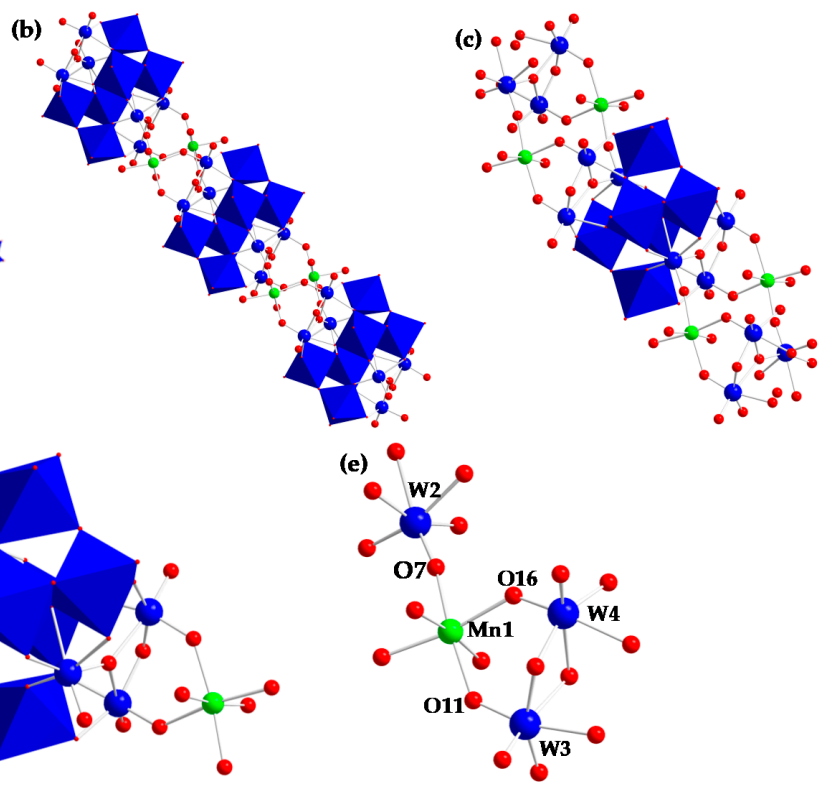

Figure 1. Polyhedral and ball-and-stick representations of 1. (a) Extended 2-D network; $(\mathbf{b}, \mathbf{c})\left[\left(\mathrm{Mn}\left(\mathrm{H}_{2} \mathrm{O}\right)_{3}\right)_{2}\left(\mathrm{H}_{2} \mathrm{~W}_{12} \mathrm{O}_{42}\right)\right]_{n}{ }^{6 n-}$ chains; (d) $\left[\left(\mathrm{Mn}\left(\mathrm{H}_{2} \mathrm{O}\right)_{3}\right)_{2}\left(\mathrm{H}_{2} \mathrm{~W}_{12} \mathrm{O}_{42}\right)\right]^{6-}$ monomer; (e) Mn-O-W connections. Blue octahedral: $\mathrm{WO}_{6}$; blue balls: "cap-type" W; red balls: O; green balls: Mn; grey balls: Na.

\subsection{Electrochemistry}

The most interesting feature of $\mathbf{1}$ is that the complex is stable enough in solution to be characterised by several electrochemical techniques. In solution, there is a $\mathrm{Mn}^{2+}$ ion firmly hanging on to each end of the dodecatungstate moieties, $\left[\mathrm{H}_{2} \mathrm{~W}_{12} \mathrm{O}_{42}\right]^{10-}$, that is to each of the two "cap-type" $\mathrm{W}$ atoms via terminal oxygen atoms.

\subsubsection{Redox Behaviours and Electro-Catalytic Properties of the Tungstic Framework}

Figure 2 shows the cyclic voltammetry curves $(\mathrm{CVs})$ of 1 at $\mathrm{pH} 3$, restricted to the first tungsten waves. These CVs exhibit three successive reduction waves peaking at $-0.39 \mathrm{~V},-0.55 \mathrm{~V}$ and $-0.68 \mathrm{~V}$ versus SCE. According to Figure 2a, no modification of the working electrode surface was observed when consecutive $\mathrm{CV}$ scans were recorded in the potential range between $+0.45 \mathrm{~V}$ to $-0.8 \mathrm{~V}$ versus SCE. The electrochemical response remained unchanged after ten successive scans towards cathodic potentials (red lines). Figure $2 \mathrm{~b}$ displays the progressive increase of both cathodic and anodic currents for each electron transfer processes occurring at the electrode surface for $\mathbf{1}$ when scanning potentials at higher rates. The variation of cathodic and anodic peak current intensities, $\mathrm{I}_{\mathrm{pc}}$ and $\mathrm{I}_{\mathrm{pa}}$, for the first and the second peaks as a function of the square root of the scan rate is shown on Figure 2c. The good linear correlation of these curves $\left(R^{2}=0.999\right)$ indicates that the electron transfer process is primarily controlled by diffusion, not only on the first two waves but also on the third one, as its shape on Figure $2 \mathrm{~b}$ may confirm. In the same medium, $0.5 \mathrm{M} \mathrm{Li}_{2} \mathrm{SO}_{4}+\mathrm{H}_{2} \mathrm{SO}_{4} / \mathrm{pH} 3$, controlled potential coulometry experiments performed at $-0.43 \mathrm{~V}$ and at $-0.57 \mathrm{~V}$ (allowing simultaneous electrolysis on the first two waves) consume $1.07 \pm 0.05$ and $2.18 \pm 0.05$ electrons per molecule of 1 respectively. This indicates that the first and the second redox processes are mono-electronic. In both cases, the reduced solution could be re-oxidized quantitatively at $+0.3 \mathrm{~V}$ in order to recover the initial state, thus confirming the stability of both the oxidized and reduced forms of $\mathbf{1}$ in this medium.

Another comparison has been drawn out between 1 and its parents' counterparts, $\left[\mathrm{H}_{2} \mathrm{~W}_{12} \mathrm{O}_{42}\right]^{10-}$ and $\left[\mathrm{H}_{2} \mathrm{~W}_{12} \mathrm{O}_{40}\right]^{6-}$, which confirms the number of electrons exchanged (see Supplementary Materials, Paragraph 1 and Figure S1) and suggests that the three compounds have close hydrodynamic radii radia in solution (see below). 

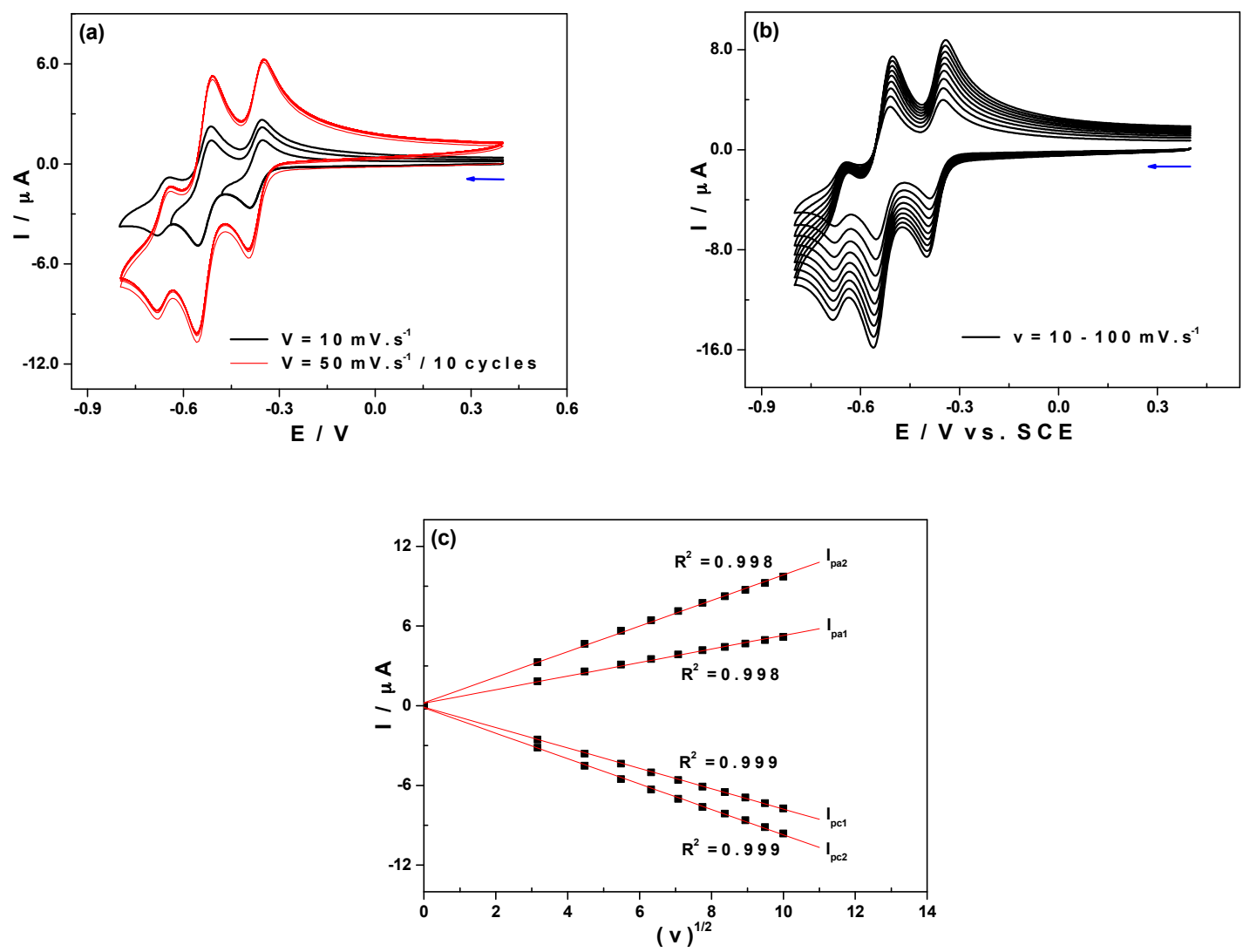

Figure 2. Cyclic voltammetry curves (CVs) of 1 at pH $3\left(0.5 \mathrm{M} \mathrm{Li}_{2} \mathrm{SO}_{4}+\mathrm{H}_{2} \mathrm{SO}_{4}\right)$; Polyoxometalate (POM) concentration: $0.5 \mathrm{mM}$. Reference electrode: Saturated Calomel Electrode (SCE). (a) Potentials were scanned between +0.4 and $-0.8 \mathrm{~V}$ at $10 \mathrm{mV} \cdot \mathrm{s}^{-1}$ (black lines) followed by ten successive cycles at $50 \mathrm{mV} \cdot \mathrm{s}^{-1}$ (red lines); (b)The scan rates from the inner to the outer curve are 10, 20, 30, 40, 50, 60, 70, 80,90 and $100 \mathrm{mV} \cdot \mathrm{s}^{-1}$; (c) Variations of cathodic and anodic peak current intensities (for the first and the second signals) as a function of the square root of the scan rate.

In order to demonstrate that the main species in solution is the $\left[\left(\mathrm{Mn}\left(\mathrm{H}_{2} \mathrm{O}\right)_{3}\right)_{2}\left(\mathrm{H}_{2} \mathrm{~W}_{12} \mathrm{O}_{42}\right)\right]^{6-}$ monomer, its diffusion coefficient (D) was determined in $0.5 \mathrm{M} \mathrm{Li}_{2} \mathrm{SO}_{4}+\mathrm{H}_{2} \mathrm{SO}_{4} / \mathrm{pH} 3$ and compared to that of metatungstate, $\left[\mathrm{H}_{2} \mathrm{~W}_{12} \mathrm{O}_{40}\right]^{6-}$, obtained in the same experimental conditions. The values of $\mathrm{D}$ obtained for 1 and for metatungstate, $\left[\mathrm{H}_{2} \mathrm{~W}_{12} \mathrm{O}_{40}\right]^{6-}$ were $5.78 \times 10^{-6} \mathrm{~cm}^{2} \cdot \mathrm{s}^{-1}$ and $1.86 \times 10^{-6} \mathrm{~cm}^{2} \cdot \mathrm{s}^{-1}$, respectively. These are of the same order of magnitude, indicating that the hydrodynamic radii of the two compounds are close to each other and therefore the main species in solution is the $\left[\left(\mathrm{Mn}\left(\mathrm{H}_{2} \mathrm{O}\right)_{3}\right)_{2}\left(\mathrm{H}_{2} \mathrm{~W}_{12} \mathrm{O}_{42}\right)\right]^{6-}$ monomer (see Supplementary Materials, paragraph 2, Figure S2 and Table S1).

\subsection{2. $\mathrm{pH}$ Influence}

When the $\mathrm{pH}$ of the electrolyte increases, in addition to the cathodic shift in potentials that is usually observed, another phenomenon appears: while between $\mathrm{pH} 2$ and 3 peak current intensities remain unchanged, at $\mathrm{pH}$ higher values, the first wave gradually disappears in favour of the redox processes occurring at more negative potentials (see Figure S3). This has also been confirmed by coulometry. As described above, at $\mathrm{pH} 3$ the overall number of electrons consumed per molecule of 1 during the two first reduction processes is equal to 2 (one electron for each peak). Another electrolysis experiment performed at $-0.73 \mathrm{~V}$ in $1.0 \mathrm{M} \mathrm{LiCH}_{3} \mathrm{COO}+\mathrm{CH}_{3} \mathrm{COO} / \mathrm{pH} 5$ (potential allowing simultaneous electrolysis on the first and the second signals) indicates an overall consumption of $2.14 \pm 0.05$ electrons. However, in this case, the charge consumed on the first and the second process is 0.64 and 1.50 electron per molecule respectively. 
From $\mathrm{pH} 3$ to $\mathrm{pH} 6$, the current peak intensity of the first reduction wave, Ipc 1 , drops steadily and loses about $85 \%$ of its initial value (see Figure 3 ). This wave is thought to completely disappear around $\mathrm{pH} 7$ but this cannot be verified as 1 rapidly decomposes above $\mathrm{pH}$. The magnitude of the peak current of the second reduction wave also decreases when the $\mathrm{pH}$ of the electrolyte increases but more moderately. The screening of the relative evolution of the peak current of both the first and the second reduction waves at $\mathrm{pH}$ values ranging from 3 to 6 is in line with the observations made during controlled potential coulometry experiments, that is, the first wave gradually disappears in favour of the second one (Figure S4). Despite the unusual behaviour of $\mathrm{I}_{\mathrm{pc} 1}$, the average shift of the reduction potential, $\mathrm{E}_{\mathrm{pc} 1}$, corresponding to this redox process is equal to $57 \mathrm{mV}$ per $\mathrm{pH}$ unit between $\mathrm{pH} 3$ and $\mathrm{pH} 6$ (Figure S4). This experimental value is very close to the theoretical expected value of $59 \mathrm{mV}$ according to the Nernst equation when one-electron and one-proton transfers are coupled, usually designated as a Proton Coupled Electron Transfer (PCET) that seems to be in competition with Electrochemical-Chemical (EC).

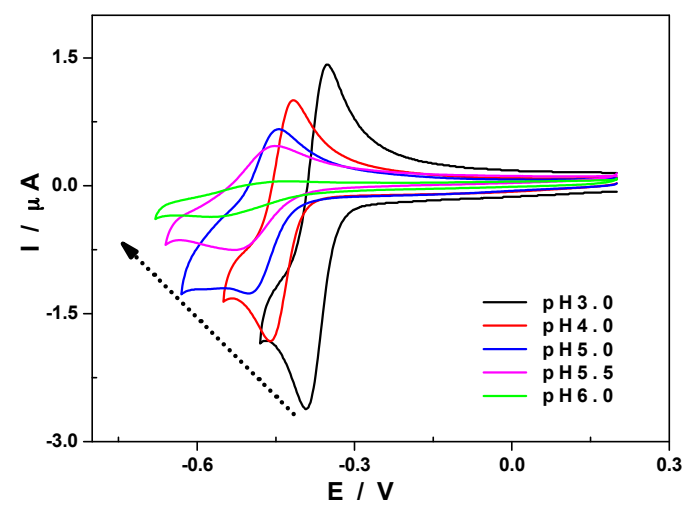

Figure 3. $\mathrm{CVs}$ of $\mathbf{1}$ at different $\mathrm{pH}$ values from 3 to 6 . Polyoxometalate concentration: $0.5 \mathrm{mM}$; scan rate: $10 \mathrm{mV} \cdot \mathrm{s}^{-1}$; working electrode: glassy carbon; reference electrode: SCE.

\subsection{Electro-Catalytic Reduction Properties}

The electrochemical reduction of $\mathrm{NO}_{2}{ }^{-}$is usually used as a classical test to evaluate the electro-catalytic activity of POMs [51]. Figure 4a compares the CVs of $\mathbf{1}$ in the absence of and upon addition of increasing amounts of nitrite, in $0.5 \mathrm{M} \mathrm{Li}_{2} \mathrm{SO}_{4}+\mathrm{H}_{2} \mathrm{SO}_{4} / \mathrm{pH} 3$, while restricted to the first reduction wave. The catalytic efficiency, $\mathrm{CAT}$, reaches a maximum of $140 \%$ for an excess parameter, $\gamma$, of 40 . The catalytic efficiency is defined as CAT $=100 \times\left[\mathrm{I}^{\mathrm{d}}\left(\mathrm{POM}+\mathrm{NO}_{2}{ }^{-}\right)-\mathrm{I}^{\mathrm{d}}(\mathrm{POM})\right] / \mathrm{I}^{\mathrm{d}}(\mathrm{POM})$ where $\mathrm{I}^{\mathrm{d}}\left(\mathrm{POM}+\mathrm{NO}_{2}{ }^{-}\right)$is the current for the reduction of the POM in the presence of $\mathrm{NO}_{2}{ }^{-}$and $\mathrm{I}^{\mathrm{d}}(\mathrm{POM})$ is the corresponding diffusion current for the POM alone and the excess parameter is the ratio between the nitrite concentration and POM concentration, $\gamma=\left[\mathrm{NO}_{2}{ }^{-}\right] /[\mathrm{POM}]$. Furthermore, the reduction of nitrite on a bare glassy carbon electrode in the same medium occurs at a more negative potential, indicating that $\mathbf{1}$ is actually responsible for the observed electro-catalytic process (Figure S5).

Nevertheless, we must consider if the good electro-catalytic efficiency towards the reduction of nitrite revealed by 1 at $\mathrm{pH} 3$ is not simply due to the fact that at this $\mathrm{pH}$ the predominant species in solution is nitrous acid, $\mathrm{HNO}_{2}$, which is easier to reduce than nitrite, $\mathrm{NO}_{2}{ }^{-}$. In fact, the pKa value related to the equilibrium between these two species, $\mathrm{HNO}_{2} \rightleftharpoons \mathrm{H}^{+}+\mathrm{NO}_{2}{ }^{-}$, is 3.2. This led us to study the same process at $\mathrm{pH} 4$ at which $\mathrm{NO}_{2}{ }^{-}$predominates with respect to $\mathrm{HNO}_{2}$. As expected, the reduction waves of $\mathbf{1}$ shifted towards more negative potential values in the absence of nitrite. In the presence of $\mathrm{NO}_{2}{ }^{-}$, a catalytic reduction current was observed which increased with the concentration of nitrite in the medium (Figure $4 \mathrm{~b}$ ). This proves that the compound $\mathbf{1}$ is efficient for the electro-catalytic reduction of the two forms co-existing in solution, nitrite and nitrous acid.

The electro-catalytic reduction of dioxygen was also explored. The formation of manganese oxide films on the working electrode actually seems to have a positive effect on the electro-catalytic reduction of $\mathrm{O}_{2}$ (see Supplementary Materials, Section S1.4 and Figure S6). 

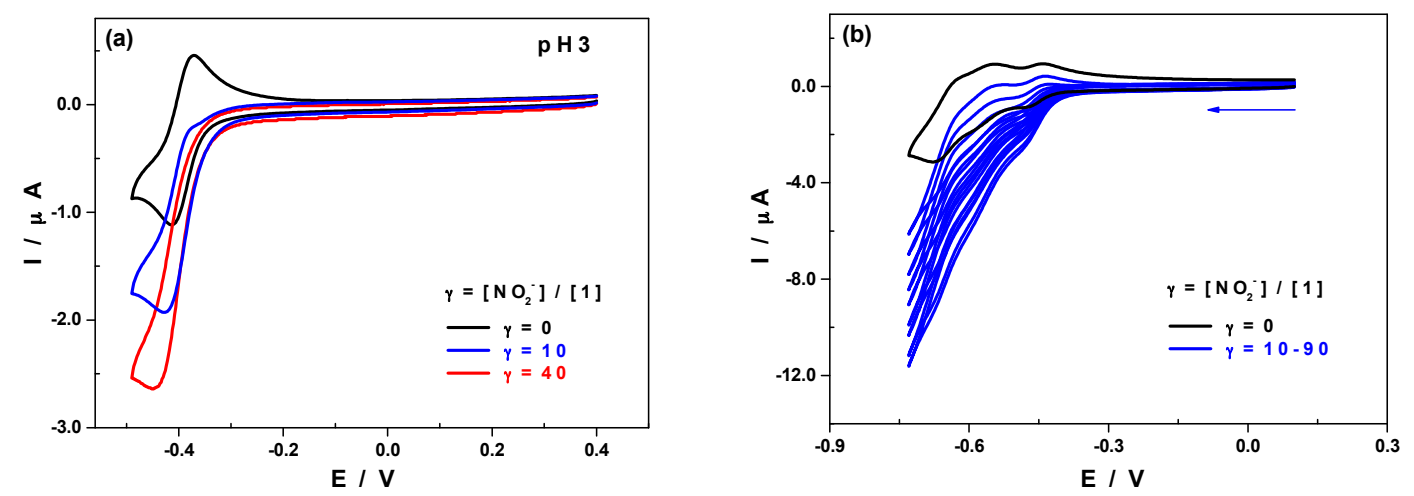

Figure 4. CVs of 1 in absence and in presence of increasing amounts of nitrite, (a) in $0.5 \mathrm{M} \mathrm{Li}_{2} \mathrm{SO}_{4}+$ $\mathrm{H}_{2} \mathrm{SO}_{4} / \mathrm{pH} 3$ and (b) in 1.0M CH $\mathrm{M}_{3} \mathrm{COOLi}+\mathrm{CH}_{3} \mathrm{COOH} / \mathrm{pH}$ 4. Polyoxometalate concentration: $0.5 \mathrm{mM}$; scan rate: $10 \mathrm{mV} \cdot \mathrm{s}^{-1}$; working electrode: glassy carbon; reference electrode: SCE. The excess parameter $\gamma$ is defined as $\gamma=\left[\mathrm{NO}_{2}-\right] /[\mathbf{1}]$.

\subsection{Redox Behaviour and Influence of the Manganese Centres}

When the potential scan is extended up to $+1.35 \mathrm{~V}$ a new anodic wave attributed to the oxidation process $\mathrm{Mn}^{2+} / \mathrm{Mn}^{4+}$ is observed. The oxidation of $\mathrm{Mn}^{2+}$ centres incorporated into POM molecules usually proceeds through a two-step mechanism: a slow electron transfer step assigned to the $\mathrm{Mn}^{2+} / \mathrm{Mn}^{3+}$ oxidation process, followed by a fast electron transfer assigned to $\mathrm{Mn}^{3+} / \mathrm{Mn}^{4+}$ (see Figure S7) $[15,34,35]$. In the present case, oxidation of the two manganese centres seems to proceed via a single step $\mathrm{Mn}^{2+} / \mathrm{Mn}^{4+}$. Indeed, on the $\mathrm{CV}$ of $\mathbf{1}$ shown in Figure 5, one can observe a sharp anodic signal with a peak at $+1.08 \mathrm{~V}$, characteristic of a fast electron transfer process. On scan reversal, the reduction of this electrochemically-generated $\mathrm{Mn}^{4+}$ species clearly proceeds through a single step. The resulting cathodic signal is characterized by a symmetrical and sharp shape corresponding to the so-called "re-dissolution" process. The current signals depicted in Figure 5 (in the anodic domain) are characteristic of adsorption-desorption processes on working electrode surfaces. In this particular case, manganese oxide species are formed and adsorbed on the working electrode surface during the forward anodic scan, are removed (reduced and re-dissolved) during the reverse cathodic scan. A new reduction wave appears, peaking at $-0.17 \mathrm{~V}$, on the second scan that is immediately recorded and can be attributed to the reduction of the remaining manganese oxides. At this point, the working electrode surface is almost completely regenerated; indeed, the tungsten waves are almost superimposable.

However, as noticeable in Figure 6, extending the potential scan to cathodic values is not sufficient for a perfect regeneration of the working electrode surface, that is, for a complete removal of the manganese oxides film deposited on the glassy carbon working electrode during the oxidation step. $\mathrm{I}_{\mathrm{pc}}$ continuously increases and $\mathrm{E}_{\mathrm{pa}}$ shifts towards less positive potentials as a proof of the modification of the electrode surface (Figure 6a). The presence of acetate anions (Figure 6b), which are better coordinating species than sulphate ions, seems to somewhat prevent the formation this manganese oxides film on the working electrode surface, the CVs being almost superimposable over successive cycling. At equal concentrations, peak currents are smaller in the acetate medium compared to the sulphate medium, while peak potentials remain invariant (Figure S8).

When the scan of potentials is extended to more anodic values, a new totally irreversible wave appears peaking at $+1.48 \mathrm{~V}$. This wave that grows during consecutive scans shows on the one hand the generation of high valence manganese species on the working electrode surface and the other hand the electro-catalytic oxidation of water by these latter species (See Figures S8B and S9). At pH 6, as expected, the electro-catalytic oxidation of $\mathrm{H}_{2} \mathrm{O}$ takes place at a less positive potential, $+1.30 \mathrm{~V}$ versus SCE, which represents a potential gain of about $50 \mathrm{mV}$, compared to the results obtained by Keita et al. under the same conditions with the sandwich-type POM $\left[\left(\mathrm{MnOH}_{2}\right)_{3}\left(\mathrm{SbW}_{9} \mathrm{O}_{33}\right)_{2}\right]^{9-}$ that contains three $\mathrm{Mn}^{3+}$ centres (Figure 7) [33]. In this medium 1.0 $\mathrm{M} \mathrm{CH}_{3} \mathrm{COOLi}+\mathrm{CH}_{3} \mathrm{COOH} / \mathrm{pH}$ 6, the reduction or desorption of manganese oxides deposited during continuous cycling between -0.79 and $+1.00 \mathrm{~V}$, 
takes place in two well-separated steps (the first at $+0.45 \mathrm{~V}$ and the second at $-0.53 \mathrm{~V}$ ) and leads to an almost perfect regeneration of the glassy carbon working electrode surface (successive CVs are rigorously superimposable, Figure S10).

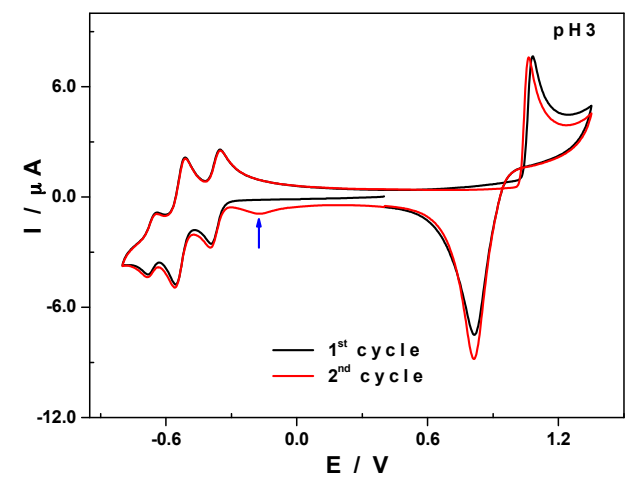

Figure 5. $\mathrm{CVs}$ of 1 in $0.5 \mathrm{M} \mathrm{Li}_{2} \mathrm{SO}_{4}+\mathrm{H}_{2} \mathrm{SO}_{4} / \mathrm{pH}$ 3. Polyoxometalate concentration: $0.5 \mathrm{mM}$; scan rate: $10 \mathrm{mV} \cdot \mathrm{s}^{-1}$; working electrode: glassy carbon; reference electrode: SCE. Potentials were initially scanned down to $-0.8 \mathrm{~V}$ (reduction region) then up to $+1.35 \mathrm{~V}$ (oxidation region); the first cycle is in black and the second in red.
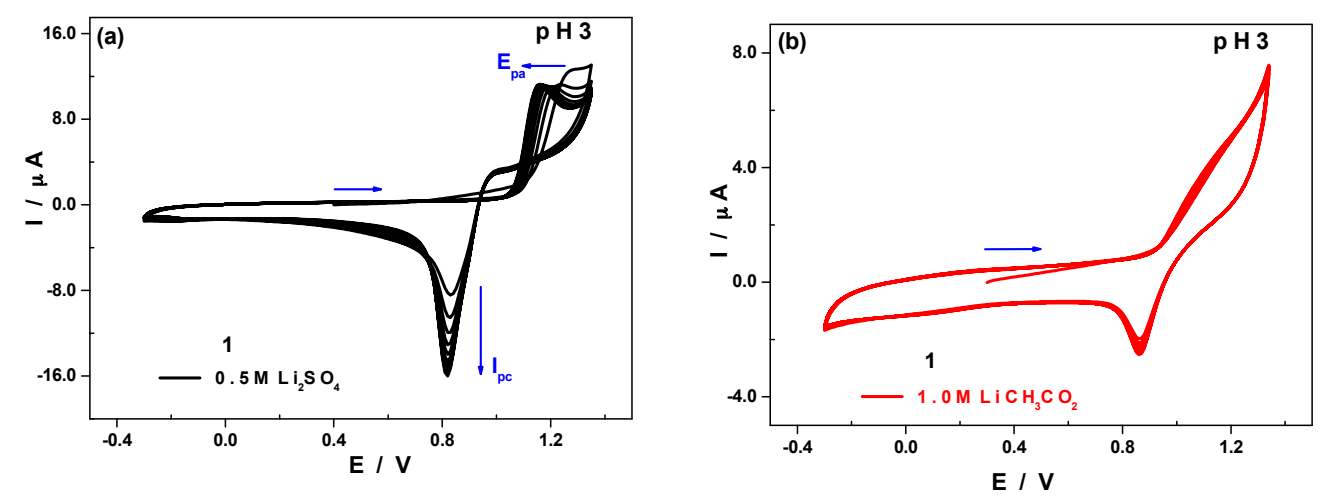

Figure 6. CVs of 1 at $\mathrm{pH} 3$ in different media; polyoxometalate concentration: $0.5 \mathrm{mM}$; scan rate: $10 \mathrm{mV} \cdot \mathrm{s}^{-1}$; working electrode: glassy carbon; reference electrode: SCE. (a) $0.5 \mathrm{M} \mathrm{Li}_{2} \mathrm{SO}_{4}+\mathrm{H}_{2} \mathrm{SO}_{4}$ : cycling (10 scans) between $-0.3 \mathrm{~V}$ and $+1.35 \mathrm{~V}$; (b) $1.0 \mathrm{M} \mathrm{CH}_{3} \mathrm{COOLi}+\mathrm{CH}_{3} \mathrm{COOH}$ : cycling (10 scans) between $-0.3 \mathrm{~V}$ and $+1.35 \mathrm{~V}$.

In order to confirm that $\mathbf{1}$ catalyses the oxidation of water on the surface of a glassy carbon electrode in the selected medium $1.0 \mathrm{M} \mathrm{CH}_{3} \mathrm{COOLi} / \mathrm{pH}$ 6, two electrolysis were carried out, first in the absence of $\mathbf{1}$ (only the electrolyte) and then in the presence of $\mathbf{1}$, at an applied potential of $+1.4 \mathrm{~V}$ versus SCE. This corresponds to the second oxidation wave of the Mn centres, which, judging from its shape, hosts a water oxidation electro-catalytic process (vide supra), which produces dioxygen. The changes in $\mathrm{O}_{2}$ concentration during the electrolysis were monitored with an oxygen probe. Each electrolysis lasted for $900 \mathrm{~s}$. In the presence of $\mathbf{1}$, the concentration of $\mathrm{O}_{2}$ rapidly increased during the first $5 \mathrm{~min}$ of the electrolysis and then it stabilised, probably due to the fact that the $\mathrm{O}_{2}$ maximum solubility in the medium was reached (Figure $8 \mathrm{a}, \mathrm{b}$ ). When the experiment was carried out in the absence of 1 (just the electrolyte present), the variation in the concentration of $\mathrm{O}_{2}$ was far less intense and even almost negligible when compared with the response obtained in the presence of 1 . The variation of the concentration of oxygen was also monitored during a cyclic voltammetry experiment carried out at a small scan rate, $\mathrm{v}=2 \mathrm{mV} \cdot \mathrm{s}^{-1}$. The outcome clearly indicates that the production of dioxygen starts at around $0.94 \mathrm{~V}$ versus SCE, reaches its maximum at $+1.4 \mathrm{~V}$ versus SCE and finally progressively decreases during the reverse scan (Figure 8c,d). 


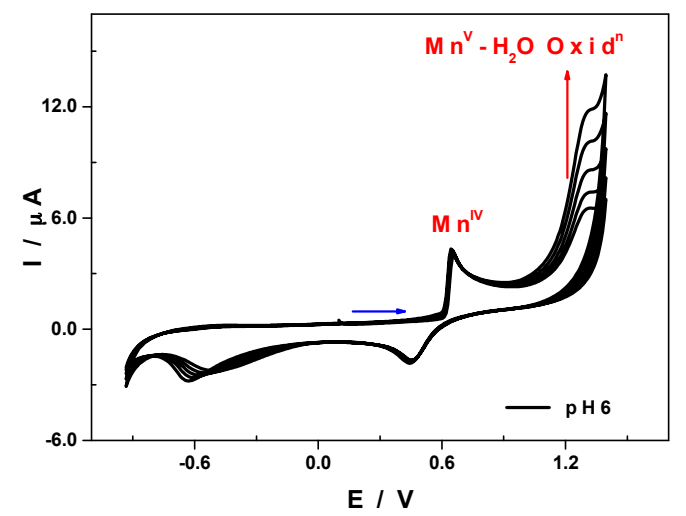

Figure 7. $\mathrm{CV}$ of 1 in $1.0 \mathrm{M} \mathrm{CH} \mathrm{CHOLi}_{3} \mathrm{CH}_{3} \mathrm{COOH} / \mathrm{pH}$ 6. Polyoxometalate concentration: $0.5 \mathrm{mM}$; scan rate: $10 \mathrm{mV} \cdot \mathrm{s}^{-1}$; working electrode: glassy carbon; reference electrode: SCE. Potentials were initially scanned from $+0.10 \mathrm{~V}$ to $+1.40 \mathrm{~V}\left(\mathrm{Mn}^{2+/ 4+}\right.$ oxidation followed by $\mathrm{Mn}^{4+/ 5+}$ and $\mathrm{H}_{2} \mathrm{O}$ electro-catalytic oxidation) then down to $-0.93 \mathrm{~V}$ (regeneration of the working electrode surface).
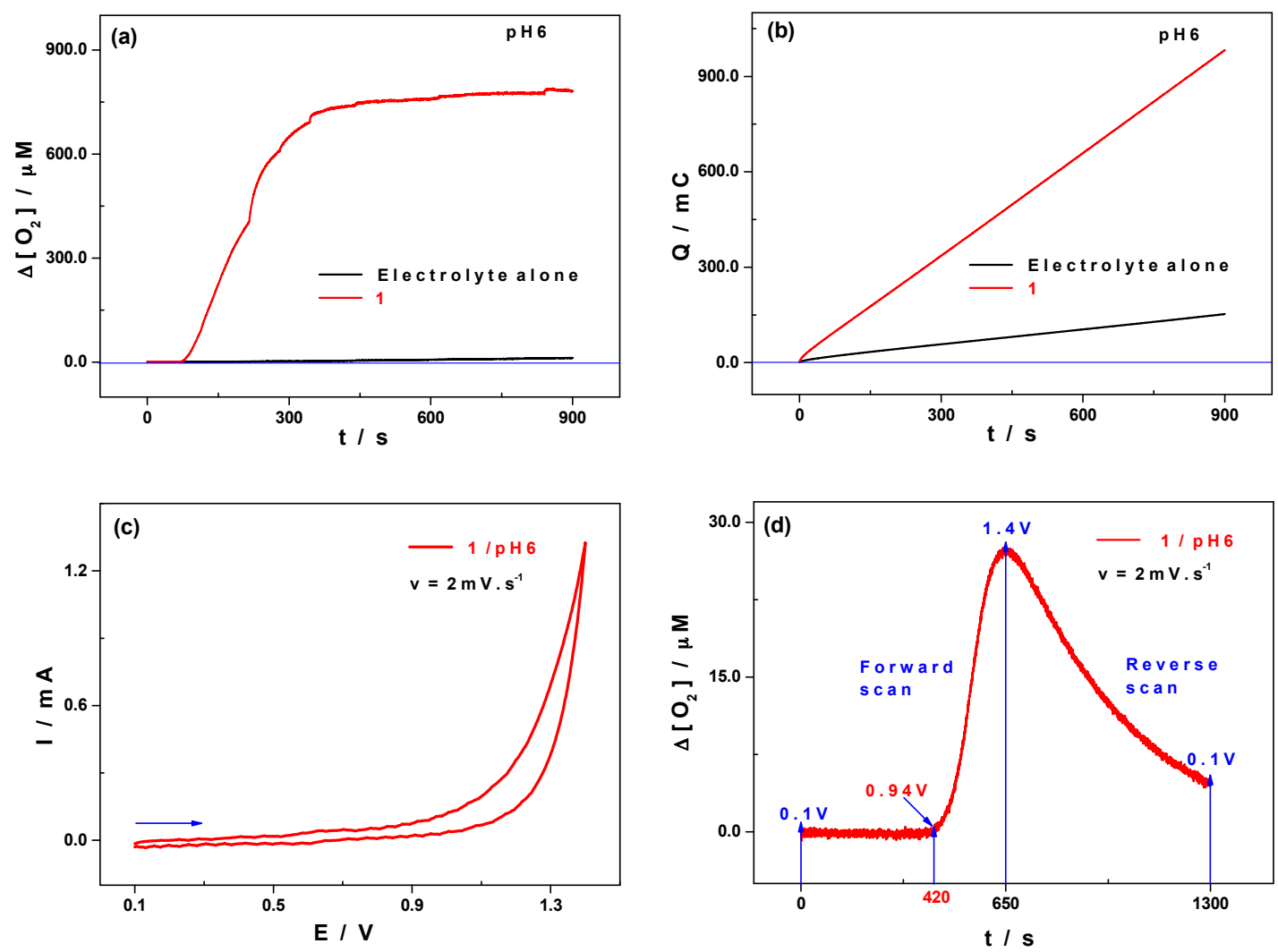

Figure 8. Electrolysis on a glassy carbon plate $\mathrm{ca} .1 \mathrm{~cm}^{2}$ in $1.0 \mathrm{M} \mathrm{CH}_{3} \mathrm{COOLi}+\mathrm{CH}_{3} \mathrm{COOH} / \mathrm{pH}$; $\mathrm{E}=1.4 \mathrm{~V}$ vs. SCE; $t=900 \mathrm{~s}$. (a) Evolution of the dioxygen concentration as a function of time in the absence (black) and in the presence (red) of $\mathbf{1}$; (b) Charge consumed as a function of time; (c) CV of $\mathbf{1}$ in the same medium at a scan rate of $2 \mathrm{mV} \cdot \mathrm{s}^{-1}$; potentials were initially scanned from $+0.10 \mathrm{~V}$ to $+1.40 \mathrm{~V}\left(\mathrm{Mn}^{2+/ 4+}\right.$ oxidation followed by $\mathrm{Mn}^{4+/ 5+}$ and $\mathrm{H}_{2} \mathrm{O}$ electro-catalytic oxidation), then back to $+0.1 \mathrm{~V}$; (d) Variation of the concentration of dioxygen in the medium of study, $\left[\mathrm{O}_{2}\right]$, as a function of the electrode potential scan (directly related with time). Polyoxometalate concentration: $0.5 \mathrm{mM}$; working electrode: glassy carbon plate $c a .1 \mathrm{~cm}^{2}$; reference electrode: SCE; auxiliary electrode, $\mathrm{Pt}$.

\subsection{Quartz Crystal Microbalance}

Experimental evidence for the formation of deposits on the surface of the working electrode during the forward anodic scan was gathered both from the coupling of a quartz crystal microbalance (QCM) to electrochemistry and from XPS analysis. As far as QCM is concerned, the vibration frequency 
variations of a quartz crystal on which the glassy carbon working electrode was mounted is followed during a cyclic voltammetry experiment (Figure 9a). The scan rate employed was $2 \mathrm{mV} \cdot \mathrm{s}^{-1}$. No variation was observed in the vibration frequency for potential values up to $0.90 \mathrm{~V}$ (Figure 9b). Between $0.90 \mathrm{~V}$ and $0.97 \mathrm{~V}$, the vibration frequency steeply decreased and the CV concomitantly registered revealed the oxidation of the $\mathrm{Mn}^{2+}$ centres into $\mathrm{Mn}^{4+}$, the shape of the wave strongly suggesting the formation of a deposit. From $0.97 \mathrm{~V}$ and up to $1.75 \mathrm{~V}$, at which the scan reversal took place, the vibration frequency kept decreasing but more slowly than before. During the reverse scan, the potential value of $0.80 \mathrm{~V}$ had to be reached in order to observe an increase in the vibration frequency of the quartz crystal. The Mn oxides previously deposited on the electrode surface were progressively reduced and re-dissolved, leading to a mass loss which resulted in an increase of the vibration frequency of the quartz crystal. However, even when the reverse scan was taken to a potential value $(-0.3 \mathrm{~V})$ more negative than the starting potential $(0.1 \mathrm{~V})$, it was not possible to go back to the initial vibration frequency value, meaning that the electrode surface was not totally regenerated.

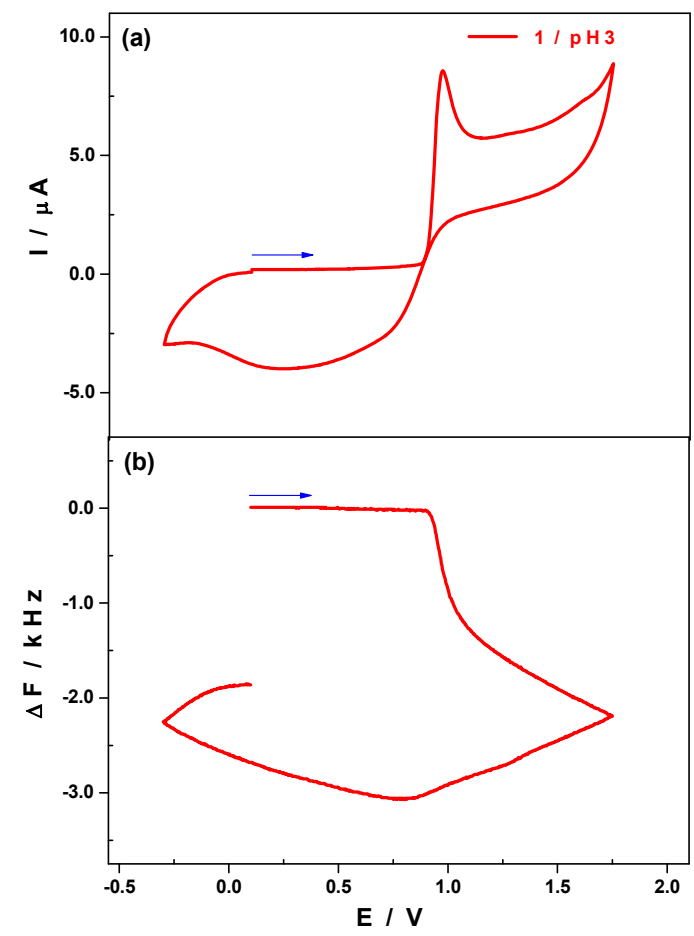

Figure 9. $\mathrm{CV}$ (a) and frequency variation as a function of the electrode potential (b) obtained with $\mathrm{H}_{2} \mathrm{~W}_{12} \mathrm{Mn}_{2}$ in $0.5 \mathrm{M} \mathrm{Li}_{2} \mathrm{SO}_{4}+\mathrm{H}_{2} \mathrm{SO}_{4} / \mathrm{pH}$ 3. Scan rate: $2 \mathrm{mV} \cdot \mathrm{s}^{-1}$. Reference electrode: SCE.

\subsection{X-Ray Photoelectron Spectroscopy (XPS)}

\subsection{1. $\mathrm{pH} 3.0$}

The surface composition of the electrodeposited films was determined by XPS. The survey spectrum shows the presence of $\mathrm{C}, \mathrm{O}, \mathrm{Mn}$ and $\mathrm{W}$ (Figure S11). Traces of $\mathrm{N}$ are also detected. The deconvolution of the $\mathrm{W} 4 \mathrm{f}$ photoemission signal exhibits two peaks with the binding energy of $\mathrm{W}$ $4 \mathrm{f}_{7 / 2}$ centred at $36.2 \pm 0.1 \mathrm{eV}$ and that of $\mathrm{W} 4 \mathrm{f}_{5 / 2}$ at $38.4 \pm 0.1 \mathrm{eV}$. The position and the shape of these peaks are representative of $\mathrm{W}$ atoms with an oxidation state of +6 . The Mn $2 p$ spectrum is split in two components at $643.2 \mathrm{eV}\left(\mathrm{Mn} 2 \mathrm{p}_{3 / 2}\right)$ and $653.0 \mathrm{eV}\left(\mathrm{Mn} \mathrm{2} \mathrm{p}_{1 / 2}\right)$ respectively. The observed binding energy values in the sample falls between $\mathrm{Mn}^{4+}$ and $\mathrm{Mn}^{6+}$, as previously reported at $641.9 \mathrm{eV}$ for $\mathrm{MnO}_{2}$ and $643.8 \mathrm{eV}$ for $\mathrm{MnO}_{4}{ }^{2-}$, respectively [75,76]. The binding energies observed are consistent with the existence of $\mathrm{Mn}^{5+}$ in a tetrahedral site according to the literature [76]. The well-known instability of $\mathrm{Mn}^{5+}$ could give rise to the appearance of $\mathrm{Mn}^{4+}$ and $\mathrm{Mn}^{7+}$ which could be related to the presence of a peak at binding energies of $645.10 \mathrm{eV}$ attributed to the formation of $\mathrm{Mn}^{7+}$ as a result of the evolution of 
$\mathrm{Mn}^{5+}$ [77]. It is possible to use the $\mathrm{Mn} 3 \mathrm{~s}$ core spectrum appearing at $84 \mathrm{eV}$ to confirm the oxidation state of Mn. A splitting of this peak resulting from the exchange interaction of $\mathrm{Mn} 3 \mathrm{~s}$ and $3 \mathrm{~d}$ electrons, leading to two photoemission final states is dependent on the number of $3 \mathrm{~d}$ electrons. The $3 \mathrm{~s}$ core levels of the $3 \mathrm{~d}$ transition metals are known to exhibit exchange splitting. Both the binding energy and the splitting of the $3 \mathrm{~s}$ level are quite sensitive to the oxidation state of the $\mathrm{Mn}$. The expected values are $6.5 \mathrm{eV}$ for $\mathrm{Mn}^{2+}, 5.5 \mathrm{eV}$ for $\mathrm{Mn}^{3+}, 4.5 \mathrm{eV}$ for $\mathrm{Mn}^{4+}$ and $<4.5 \mathrm{eV}$ for $\mathrm{Mn}^{5+}$. However, an overlapping of the $\mathrm{W} 5 \mathrm{~s}$ signal appearing at $77 \mathrm{eV}$ makes it difficult to determine the oxidation state of $\mathrm{Mn}$ from $\mathrm{Mn}$ 3s core level spectrum.

\subsection{2. $\mathrm{pH} 6.0$}

Analogous electrodeposition experiments have been performed at $\mathrm{pH} 6.0$ by applying an anodic potential of $1.4 \mathrm{~V} / \mathrm{SCE}$ for $15 \mathrm{~min}$ on a glassy carbon surface. The survey XPS spectrum shows the presence of $\mathrm{C}, \mathrm{O}, \mathrm{Mn}$ and $\mathrm{W}$ (Figure 10a). The deconvolution of the $\mathrm{W}$ 4f peak exhibits two components with the binding energy of $W 4 f_{7 / 2}$ centred at $36.2 \pm 0.1 \mathrm{eV}$ and that of $\mathrm{W} 4 \mathrm{f}_{5 / 2}$ at $38.4 \pm 0.1 \mathrm{eV}$ (Figure 10c) which are attributed to the presence of $\mathrm{W}$ atoms with an oxidation state of +6 . The high-resolution spectrum of Mn 2p shows two main peaks at $641.9 \mathrm{eV}$ and $653.5 \mathrm{eV}$ (Figure 10b) with an energy difference of $11.8 \mathrm{eV}$ attributed to the $\mathrm{Mn} 2 \mathrm{p}_{3 / 2}$ and $\mathrm{Mn} 2 \mathrm{p}_{1 / 2}$ respectively. These binding energies are in good agreement with the presence of $\mathrm{MnO}_{2}$ on the carbon surface [43]. Furthermore, the amounts of Mn 2p detected on the electrode surface are much higher at $\mathrm{pH} 6.0$ than at $\mathrm{pH} 3.0$, resulting in an important decrease of the $\mathrm{W} / \mathrm{Mn}$ ratio at higher $\mathrm{pH}$. This decrease is due to a larger amount of Mn whereas the amount of $\mathrm{W}$ detected is of the same order in both cases.
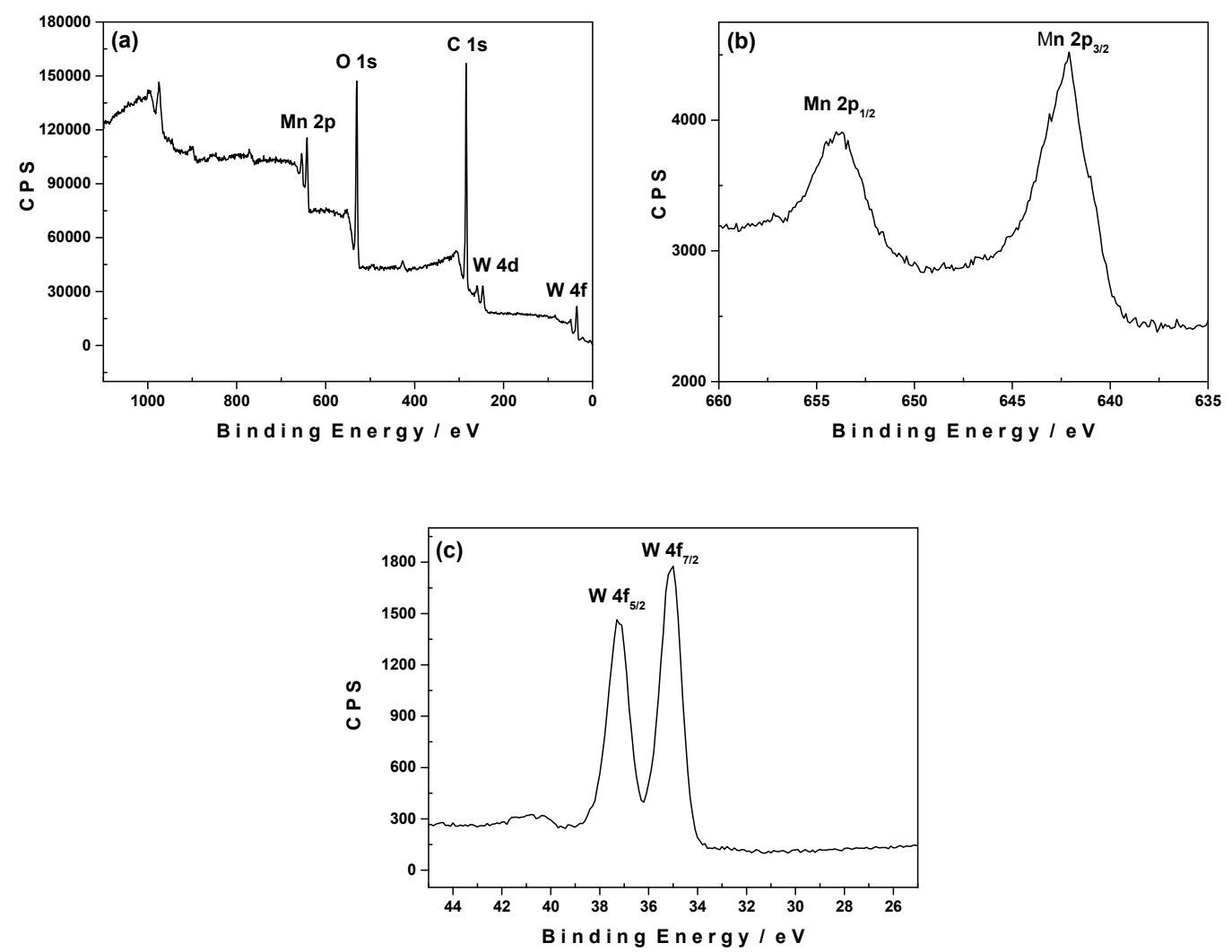

Figure 10. (a) XPS survey spectrum for a 1-modified glassy carbon electrode by induced electrochemical deposition at $+1.4 \mathrm{~V}$ vs. SCE in $1.0 \mathrm{M} \mathrm{CH}_{3} \mathrm{COOLi}+\mathrm{CH}_{3} \mathrm{COOH} / \mathrm{pH}$. The POM concentration in the solution was $0.5 \mathrm{mM}$; (b) Mn 2p core level spectrum; (c) W 4f core level spectrum.

The elemental atomic concentrations of the surface modified electrodes prepared from a solution containing 1 are summarised in Table 2 as a function of the $\mathrm{pH}$. 
Table 2. Elemental atomic concentrations of the surface modified electrodes determined by XPS.

\begin{tabular}{cccccc}
\hline \multirow{2}{*}{$\mathbf{p H}$} & \multicolumn{4}{c}{ Atomic Concentration \% } & \multirow{2}{*}{ W/Mn } \\
\cline { 2 - 5 } & C 1s & O 1s & W 4f & Mn 2p & \\
\hline 3.0 & 80.7 & 14.3 & 4.1 & 0.9 & 4.4 \\
\hline 6.0 & 77.3 & 13.3 & 5.1 & 4.3 & 1.2 \\
\hline
\end{tabular}

\section{Materials and Methods}

Pure water was used throughout. It was obtained from a RiOs 8 unit followed by a Millipore-Q Academic purification set (Merck KGaA, Darmstadt, Germany). All reagents were of high-purity grade and were used as purchased without further purification. Elemental analysis was performed by the Service Central d'Analyse CNRS, Solaize, France. The IR spectra (Figure S15) were recorded with KBr pellets on a Nicolet Magna IR Spectrometer 550 spectrophotometer (Nicolet Instrument Corporation, Madison, WI, USA). The UV-visible spectra (SI, paragraph 8) were recorded on a Perkin-Elmer Lambda 19 spectrophotometer (Perkin Elmer, Norwalk, CT, USA) with $2.5 \times 10^{-5} \mathrm{M}$ solutions of the relevant polyanion. Matched $1.00 \mathrm{~mm}$ optical path quartz cuvettes were used. The composition of the various media was as follows: (1) sulphate buffers, for $\mathrm{pH} 1$ to 3, $0.5 \mathrm{M} \mathrm{Li}_{2} \mathrm{SO}_{4}+\mathrm{H}_{2} \mathrm{SO}_{4}$ and for $\mathrm{pH} 7,0.5 \mathrm{M}$ $\mathrm{Li}_{2} \mathrm{SO}_{4}+0.05 \mathrm{M}$ Tris(Hydroxyl)Amino Methane (THAM); (2) acetate buffers, for $\mathrm{pH} 2$ to 3, $1.0 \mathrm{M}$ $\mathrm{LiCH}_{3} \mathrm{COO}+\mathrm{CClH}_{2} \mathrm{COOH}$ and for $\mathrm{pH} 4$ to 6, $1.0 \mathrm{M} \mathrm{LiCH}_{3} \mathrm{COO}+\mathrm{CH}_{3} \mathrm{COOH}$.

\subsection{Synthesis of $\left[\left(\mathrm{Mn}\left(\mathrm{H}_{2} \mathrm{O}\right)_{3}\right)_{2}\left(\mathrm{H}_{2} \mathrm{~W}_{12} \mathrm{O}_{42}\right)\right]^{6-}$ (1)}

This compound was obtained when attempting to prepare the sandwich-type complex $\left[\mathrm{Mn}_{2}\left(\mathrm{MnOH}_{2}\right)_{2}\left(\mathrm{ZnW}_{9} \mathrm{O}_{34}\right)_{2}\right]^{12-}$, using a procedure adapted from the one described for $\left[\mathrm{Mn}_{2}\left(\mathrm{MnOH}_{2}\right)_{2}\left(\mathrm{AsW}_{9} \mathrm{O}_{33}\right)_{2}\right]^{12-}$ by Krebs et al. [78].

A $6.0 \mathrm{~g}$ sample of $\mathrm{Na}_{2} \mathrm{WO}_{4} \cdot 2 \mathrm{H}_{2} \mathrm{O}(\sim 18.20 \mathrm{mmol})$ dissolved in $10 \mathrm{~mL}$ of water was slowly added upon stirring at room temperature to a $0.22 \mathrm{~g}$ sample of $\mathrm{Zn}\left(\mathrm{CH}_{3} \mathrm{COO}\right)_{2} \cdot 2 \mathrm{H}_{2} \mathrm{O}(\sim 1.01 \mathrm{mmol})$ dissolved in $35 \mathrm{~mL}$ of a $0.5 \mathrm{M} \mathrm{CH}_{3} \mathrm{COONa} / 0.5 \mathrm{M} \mathrm{CH}_{3} \mathrm{COOH}$ (pH 4.6) buffer. The cloudy and white solution obtained was heated at $50{ }^{\circ} \mathrm{C}$ for about $15 \mathrm{~min}$. Then, $0.60 \mathrm{~g}$ of $\mathrm{MnCl}_{2} \cdot 4 \mathrm{H}_{2} \mathrm{O}(\sim 3.03 \mathrm{mmol})$ was added to the solution resulting in a colour change from white to yellow and the simultaneous appearance of a precipitate. At this point, the yellow suspension was heated at $80^{\circ} \mathrm{C}$ for about $1 \mathrm{~h}$, cooled at room temperature and filtered with a fine porosity fritted glass. The very fine yellowish powder was discarded and the clear yellow solution was treated with $15 \mathrm{~mL}$ of a $1 \mathrm{M} \mathrm{KCl}$ solution. A pale yellow solid precipitated in solution that was cooled and kept at $4{ }^{\circ} \mathrm{C}$ overnight. The yellowish precipitate was collected by filtration, washed twice with ethanol and dried in open-air $(2.51 \mathrm{~g} ; 43.9 \%$ based on $\mathrm{W})$ corresponding to $\mathrm{K}_{2} \mathrm{Na}_{4}\left[\left(\mathrm{Mn}\left(\mathrm{H}_{2} \mathrm{O}\right)_{3}\right)_{2}\left(\mathrm{H}_{2} \mathrm{~W}_{12} \mathrm{O}_{42}\right)\right] \cdot 28 \mathrm{H}_{2} \mathrm{O}$. IR (KBr pellet): $1617(\mathrm{~m})$, 1562(m), 1403(m), 909(m), 846(m), 784(w), 738(m), 689(m), 525(w), 412(m). Anal. Calcd. (found) for $\mathrm{K}_{2} \mathrm{Na}_{4}\left[\left(\mathrm{Mn}\left(\mathrm{H}_{2} \mathrm{O}\right)_{3}\right)_{2}\left(\mathrm{H}_{2} \mathrm{~W}_{12} \mathrm{O}_{42}\right)\right] \cdot 28 \mathrm{H}_{2} \mathrm{O}: \mathrm{W}, 58.48$ (57.1); Mn, 2.91 (2.78); $\mathrm{Na}, 2.44$ (2.73) $\mathrm{K}, 2.07$ (3.01). [M.W. $=3772.28]$.

\subsection{X-ray Crystallography}

Intensity data collection was carried out with a Bruker Nonius X8 APEX 2 diffractometer (Bruker AXS, Madison, WI, USA) equipped with a CCD bidimensional detector using the monochromatised wavelength $\lambda(\mathrm{Mo} \mathrm{K} \alpha)=0.71073 \AA$. The data were collected at $150 \mathrm{~K}$. The absorption correction was based on multiple and symmetry-equivalent reflections in the data set using the SADABS program [79] based on the method of Blessing [80]. The structures were solved by direct methods and refined by full-matrix least-squares using the SHELX-TL package [81]. A discrepancy between the formula determined by elemental analysis and the formula deduced from the crystallographic atom list was encountered mainly due to the difficulty in localising all the disordered water molecules and alkali 
counter-ions. Crystallographic data are given in Table 3. Comparisons of selected bond lengths and bond angles are given in Table 1.

Table 3. Crystallographic data for $\mathbf{1}$.

\begin{tabular}{ll}
\hline Empirical formula & $\mathrm{H}_{62} \mathrm{~K}_{2} \mathrm{Mn}_{2} \mathrm{Na}_{4} \mathrm{O}_{76} \mathrm{~W}_{12}$ \\
Formula weight, $\mathrm{g}$ & 3764.74 \\
Crystal system & Triclinic \\
Space group & $\mathrm{P}-1$ \\
$a / \AA$ & $12.132(3)$ \\
$b / \AA$ & $12.290(3)$ \\
$c / \AA$ & $13.130(4)$ \\
$\alpha /$ deg. & $73.394(10)$ \\
$\beta /$ deg. & $67.727(10)$ \\
$\alpha /$ deg. & $73.205(11)$ \\
$V / \AA^{3}$ & $1699.7(8)$ \\
$Z$ & 1 \\
$\rho_{\text {calc }} / \mathrm{g} \cdot \mathrm{cm}^{-3}$ & 3.678 \\
$\mu / \mathrm{mm}-1$ & 20.846 \\
Data/Parameters & $9922 / 460$ \\
$R_{\text {int }}$ & 0.0492 \\
$\mathrm{GOF}$ & 1.174 \\
$R(>2 \sigma(\mathrm{I}))$ & $R_{1}{ }^{a}=0.0340$ \\
& $w R_{2}^{b}=0.0914$ \\
\hline \multirow{2}{*}{$R_{1}=\frac{\sum\left|F_{o}\right|-\left|F_{c}\right|}{\sum\left|F_{c}\right|}{ }^{b} w R_{2}$} & $=\sqrt{\frac{\sum w\left(F_{o}^{2}-F_{c}^{2}\right)^{2}}{\sum w\left(F_{o}^{2}\right)^{2}} .}$
\end{tabular}

Further details on the crystal structure investigation may be obtained from the FIZ Karlsruhe-Leibniz-Institut für Informationsinfrastruktur, Hermann-von-Helmholtz-Platz 1, 76344 Eggenstein-Leopoldshafen (Fax +49-7247-808-666; E-mail: crysdata@fiz-karlsruhe.de) on quoting the depository number CSD-425294.

\subsection{Electrochemical Experiments}

Electrochemical data was obtained using an EG \& G 273A driven by a PC with the M270 software (M270, PAR AMETEK, Oak Ridge, TN, USA). A one-compartment cell with a standard three-electrode configuration was used for cyclic voltammetry experiments. The same media as for UV-visible spectroscopy were used for electrochemistry but the polyanion concentration was $5 \times 10^{-4} \mathrm{M}$. Prior to each experiment; solutions were de-aerated thoroughly for at least $30 \mathrm{~min}$ with pure Ar. A positive pressure of this gas was maintained during subsequent work. All cyclic voltammograms were recorded at a scan rate of $10 \mathrm{mV} \cdot \mathrm{s}^{-1}$ unless otherwise stated. All experiments were performed at room temperature, which is controlled and fixed for the lab at $20^{\circ} \mathrm{C}$. The reference electrode was a saturated calomel electrode (SCE), the counter electrode a platinum gauze of large surface area; both electrodes were separated from the bulk electrolyte solution via fritted compartments filled with the same electrolyte. The working electrode was a $3 \mathrm{~mm}$ OD glassy carbon disc (GC, Mersen, France). The pre-treatment of this electrode before each experiment, adapted from the procedure of Keita and co-workers [82], was as follows: 1. Fine polishing using diamond pastes (DP Diamond-Struers) of decreasing grain size ( $15 \mathrm{~min}$ with a grain size of $6 \mu \mathrm{m}, 15 \mathrm{~min}$ with a grain size of $3 \mu \mathrm{m}$ and $30 \mathrm{~min}$ with a grain size of $1 \mu \mathrm{m}$ ). The electrode then underwent two successive $5 \mathrm{~min}$ ultrasonic washing in ethanol and in Millipore water respectively. Results were very reproducible from one experiment to another and slight variations observed over successive runs are rather attributed to the uncertainty associated with the detection limit of our equipment (potentiostat, hardware and software) and not to working electrode pre-treatment neither to possible variations in temperature. 


\subsection{XPS Analysis}

X-Ray Photoelectron spectroscopy (XPS) measurements were carried out on glassy carbon surfaces with an Axis-165 from Kratos Analytical (Manchester, UK) equipped with an Al anode (Al K $\alpha$ X-rays at $1486.6 \mathrm{eV}$ ). Spectra were recorded with an energy pass of $20 \mathrm{eV}$ for core level spectra and $80 \mathrm{eV}$ for survey spectra. The data were obtained at room temperature and typically the operating pressure in the analyses chamber was below $10^{-9}$ Torr. All binding energies were referenced to that of adventitious carbon binding energy at $\mathrm{C} 1 \mathrm{~s}=284.9 \mathrm{eV}$. The core level spectra were peak-fitted using the CasaXPS software (version 2.3.19, Casa Software Ltd., Teignmouth, UK). The core level spectra were used to evaluate the atomic concentration of the species present at carbon electrode surface. The atomic concentration (at \%) of each element was determined, by assuming a homogeneous layer, from the relative peak areas of the spectrum and the corresponding sensitivity factors according to the equation below, where $\mathrm{A}_{i}$ is the peak area of the element $i$ and $\mathrm{s}_{i}$ is the sensitivity factor for this element.

$$
\text { at } \%=\frac{\left(\frac{A i}{s i}\right)}{\sum\left(\frac{A i}{s i}\right)}
$$

Sensitivity factor values corresponding to the Kratos spectrometer were used in the quantification analysis.

\section{Conclusions}

The Mn-containing polyoxometalate based on paradodecatungstate- $\mathrm{B}$ moieties, $\left[\left(\mathrm{Mn}\left(\mathrm{H}_{2} \mathrm{O}\right)_{3}\right)_{2}\left(\mathrm{H}_{2} \mathrm{~W}_{12} \mathrm{O}_{42}\right)\right]^{6-}$, was obtained by reaction of $\mathrm{Mn}^{2+}$ and $\mathrm{WO}_{4}{ }^{2-}$ ions in acetate buffer in the presence of $\mathrm{Zn}^{2+}$ ions. In the solid, crystallography studies show that the $\mathrm{Mn}^{2+}$ ions are 6-coordinate and surface bound to terminal oxygens of two neighbouring dodecatungstate units to form an extended 2-D network. Interestingly, UV-visible spectroscopy and electrochemical analysis confirm that in aqueous solution the active species is the monomeric unit, $\left[\left(\mathrm{Mn}\left(\mathrm{H}_{2} \mathrm{O}\right)_{3}\right)_{2}\left(\mathrm{H}_{2} \mathrm{~W}_{12} \mathrm{O}_{42}\right)\right]^{6-}$. This compound is stable enough in aqueous solution between $\mathrm{pH} 1$ and 6 to be fully characterised by cyclic voltammetry, controlled potential coulometry and crystal quartz microbalance. Corresponding $\mathrm{CVs}$ recorded in different media revealed that the reduction of $\mathrm{W}$ centres proceeds in three steps that are $\mathrm{pH}$ dependent. The $\mathrm{Mn}^{2+}$ centres are oxidised to the $\mathrm{Mn}^{4+}$ state in a single step which depends on the $\mathrm{pH}$ and on the composition of the electrolyte. This oxidation is concomitant with the formation of a film of oxides deposited on the surface of the working electrode. The shape of the return wave and the QCM results show that this film is totally redissolved during the reverse scan upon the reduction of $\mathrm{Mn}^{4+}$ back into $\mathrm{Mn}^{2+}$. XPS results obtained after the electrochemical deposition at $\mathrm{pH} 3$ and 6 show the existence of all the elements present in the structure of 1 . However, the composition of the electrodeposited layer at $\mathrm{pH} 6$ shows a very low $\mathrm{W} / \mathrm{Mn}$ experimental ratio of 1.2 compared to the theoretical expected value of 6 present in the starting material 1. The $\mathrm{W} / \mathrm{Mn}$ ratio obtain at $\mathrm{pH} 3$ is much higher, 4.4, than that at $\mathrm{pH} 6$ but still lower than the expected theoretical value. These observations suggest a decomposition of $\mathbf{1}$ resulting from the application of a high positive potential for a long time. Additionally, 1 also demonstrates electro-catalytic activity as demonstrated for the reduction of nitrite and of dioxygen and also for the oxidation of water. These results illustrate the importance of continuing the development of new POMs that can accumulate several " $\mathrm{d}$ " centres with expected applications in electro-catalysts.

Supplementary Materials: The following are available online at http:/ / www.mdpi.com/2304-6740/7/2/15/s1, complementary data on electrochemistry and the electro-catalytic reduction of $\mathrm{NO}_{2}^{-}$and $\mathrm{O}_{2}$, the electro-catalytic oxidation of $\mathrm{H}_{2} \mathrm{O}$, UV-Visible spectra, FT-IR spectra, XPS spectra, Thermogravimetric analysis, the CIF and the checkCIF. CSD 426148 contains the supplementary crystallographic data for this paper. These data can be obtained free of charge from FIZ Karlsruhe via www.ccdc.cam.ac.uk/structures.

Author Contributions: The preparation of the manuscript was made by all authors. A.-L.T., P.d.O. and A.W.: careful follow-up and improvement of the manuscript. J.M.: acquired the Single Crystal X-ray diffraction. R.C.H.: analysed the Single Crystal X-ray diffraction results and wrote that part. N.V.: acquired and analysed the XPS 
spectra and wrote that part. I.M.M.: General idea, syntheses, electrochemical and electro-catalytic studies and writing up of the manuscript.

Funding: This research received no external funding.

Acknowledgments: I.M.M thanks the Universite Paris-Sud and the CNRS for financial support. N.V. thanks the Université de Lorraine and the CNRS for financial support. J.M. thanks the Université de Versailles and the CNRS for financial support.

Conflicts of Interest: The authors declare no conflict of interest.

\section{References}

1. Gumerova, N.I.; Rompel, A. Synthesis, structures and applications of electron-rich polyoxometalates. Nat. Rev. Chem. 2018, 2, 0112. [CrossRef]

2. Katsoulis, D.E. A Survey of Applications of Polyoxometalates. Chem. Rev. 1998, 98, 359-388. [CrossRef] [PubMed]

3. Walsh, J.J.; Bond, A.M.; Forster, R.J.; Keyes, T.E. Hybrid polyoxometalate materials for photo(electro-) chemical applications. Coord. Chem. Rev. 2016, 306, 217-234. [CrossRef]

4. Contant, R.; Herveb, G. The heteropolyoxotungstates: Relationships between routes of formation and structures. Rev. Inorg. Chem. 2002, 22, 63-112. [CrossRef]

5. Long, D.-L.; Burkholder, E.; Cronin, L. Polyoxometalate clusters, nanostructures and materials: From self assembly to designer materials and devices. Chem. Soc. Rev. 2007, 36, 105-121. [CrossRef] [PubMed]

6. Long, D.-L.; Tsunashima, R.; Cronin, L. Polyoxometalates: Building Blocks for Functional Nanoscale Systems. Angew. Chem. Int. Ed. 2010, 49, 1736-1758. [CrossRef] [PubMed]

7. Müller, A.; Kögerler, P. From simple building blocks to structures with increasing size and complexity. Coord. Chem. Rev. 1999, 182, 3-17. [CrossRef]

8. Pope, M.T.; Kortz, U. Polyoxometalates: Update Based on the Original Article by Michael T. Pope, Encyclopedia of Inorganic Chemistry @ 2005, John Wiley \& Sons, Ltd. In Encyclopedia of Inorganic and Bioinorganic Chemistry; John Wiley \& Sons: New York, NY, USA, 2012.

9. Pope, M. Heteropoly and Isopoly Oxometalates; Springer: Berlin/Heidelberg, Germany, 1983; p. XIII. 180p.

10. Keita, B.; Mbomekalle, I.M.; Nadjo, L.; Contant, R. $\left[\mathrm{H}_{4} \mathrm{AsW}_{18} \mathrm{O}_{2}\right]^{7-}$, a novel Dawson heteropolyanion and two of its sandwich-type derivatives $\left[\mathrm{Zn}_{4}\left(\mathrm{H}_{2} \mathrm{O}\right)_{2}\left(\mathrm{H}_{4} \mathrm{AsW}_{15} \mathrm{O}_{56}\right)_{2}\right]^{18-},\left[\mathrm{Cu}_{4}\left(\mathrm{H}_{2} \mathrm{O}\right)_{2}\left(\mathrm{H}_{4} \mathrm{AsW}_{15} \mathrm{O}_{56}\right)_{2}\right]^{18-}$ : Cyclic voltammetry and electrocatalytic properties towards nitrite and nitrate. Electrochem. Commun. 2001, 3, 267-273. [CrossRef]

11. Mbomekalle, I.M.; Keita, B.; Nadjo, L.; Contant, R.; Belai, N.; Pope, M.T. Rationalization and improvement of the syntheses of two octadecatungstoarsenates: The novel $\alpha-\mathrm{K}_{7}\left[\mathrm{H}_{4} \mathrm{AsW}_{18} \mathrm{O}_{62}\right] \cdot 18 \mathrm{H}_{2} \mathrm{O}$ and the well known symmetrical $\alpha-\mathrm{K}_{6}\left[\mathrm{As}_{2} \mathrm{~W}_{18} \mathrm{O}_{62}\right] \cdot 14 \mathrm{H}_{2} \mathrm{O}$. Inorg. Chim. Acta 2003, 342, 219-228. [CrossRef]

12. Mbomekalle, I.-M.; Lu, Y.W.; Keita, B.; Nadjo, L. Simple, high yield and reagent-saving synthesis of pure $\alpha-\mathrm{K}_{6} \mathrm{P}_{2} \mathrm{~W}_{18} \mathrm{O}_{62} \cdot 14 \mathrm{H}_{2} \mathrm{O}$. Inorg. Chem. Commun. 2003, 7, 86-90. [CrossRef]

13. Mbomekalle, I.M.; Lu, Y.W.; Keita, B.; Nadjo, L.; Neiwert, W.A.; Hardcastle, K.I.; Hill, C.L.; Anderson, T.M. Crystallographic studies of a molybdenum-rich diarsenotungstate and reaction of Fe(III) with its isomerically pure $\alpha 1$ - and $\alpha 2$-monolacunary derivatives. Eur. J. Inorg. Chem. 2005, 1547-1551. [CrossRef]

14. Mbomekalle, I.M.; Mialane, P.; Dolbecq, A.; Marrot, J.; Sécheresse, F.; Berthet, P.; Keita, B.; Nadjo, L. Rational Synthesis, Structure, Magnetism and Electrochemistry of Mixed Iron-Nickel-Containing Wells-Dawson-Fragment-Based Sandwich-Type Polyoxometalates. Eur. J. Inorg. Chem. 2009, 2009, 5194-5204. [CrossRef]

15. Lebrini, M.; Mbomekalle, I.M.; Dolbecq, A.; Marrot, J.; Berthet, P.; Ntienoue, J.; Secheresse, F.; Vigneron, J.; Etcheberry, A. Manganese(III)-containing Wells-Dawson sandwich-type polyoxometalates: Comparison with their manganese(II) counterparts. Inorg. Chem. 2011, 50, 6437-6448. [CrossRef] [PubMed]

16. Mbomekallé, I.-M.; Bassil, B.S.; Suchopar, A.; Keita, B.; Nadjo, L.; Ammam, M.; Haouas, M.; Taulelle, F.; Kortz, U. Improved Synthesis, Structure and Solution Characterization of the Cyclic 48-Tungsto-8-Arsenate(V), $\left[\mathrm{H}_{4} \mathrm{As}_{8} \mathrm{~W}_{48} \mathrm{O}_{184}\right]^{36-}$. J. Clust. Sci. 2013, 25, 277-285. [CrossRef]

17. Parent, L.; de Oliveira, P.; Teillout, A.-L.; Dolbecq, A.; Haouas, M.; Cadot, E.; Mbomekalle, I.M. Synthesis and characterisation of the europium(III) dimolybdo-enneatungsto-silicate dimer, $\left[\mathrm{Eu}\left(\alpha-\mathrm{SiW}_{9} \mathrm{Mo}_{2} \mathrm{O}_{39}\right)_{2}\right]^{13-}$. Inorganics 2015, 3, 341-354. [CrossRef] 
18. Finke, R.G.; Droege, M.W. Trivacant heteropolytungstate derivatives. 2. Synthesis, characterization and tungsten-183 NMR of $\mathrm{P}_{4} \mathrm{~W}_{30} \mathrm{M}_{4}\left(\mathrm{H}_{2} \mathrm{O}\right)_{2} \mathrm{O}_{112}{ }^{16-}(\mathrm{M}=\mathrm{Co}, \mathrm{Cu}, \mathrm{Zn})$. Inorg. Chem. 1983, 22, 1006-1008. [CrossRef]

19. Weakley, T.J.R.; Finke, R.G. Single-crystal x-ray structures of the polyoxotungstate salts $\mathrm{K}_{8.3} \mathrm{Na}_{1.7}\left[\mathrm{Cu}_{4}\left(\mathrm{H}_{2} \mathrm{O}\right)_{2}\left(\mathrm{PW}_{9} \mathrm{O}_{34}\right)_{2}\right] \cdot 24 \mathrm{H}_{2} \mathrm{O}$ and $\mathrm{Na}_{14} \mathrm{Cu}\left[\mathrm{Cu}_{4}\left(\mathrm{H}_{2} \mathrm{O}\right)_{2}\left(\mathrm{P}_{2} \mathrm{~W}_{15} \mathrm{O}_{56}\right)_{2}\right] \cdot 53 \mathrm{H}_{2} \mathrm{O}$. Inorg. Chem. 1990, 29, 1235-1241. [CrossRef]

20. Gomez-Garcia, C.J.; Borras-Almenar, J.J.; Coronado, E.; Ouahab, L. Single-Crystal X-ray Structure and Magnetic Properties of the Polyoxotungstate Complexes $\mathrm{Na}_{16}\left[\mathrm{M}_{4}\left(\mathrm{H}_{2} \mathrm{O}\right)_{2}\left(\mathrm{P}_{2} \mathrm{~W}_{15} \mathrm{O}_{56}\right)_{2}\right] \cdot n \mathrm{H}_{2} \mathrm{O}\left(\mathrm{M}=\mathrm{Mn}^{\mathrm{II}}\right.$, $\left.n=53 ; \mathrm{M}=\mathrm{Ni}^{\mathrm{II}}, n=52\right)$ : An Antiferromagnetic $\mathrm{Mn}^{\mathrm{II}}$ Tetramer and a Ferromagnetic $\mathrm{Ni}^{\mathrm{II}}$ Tetramer. Inorg. Chem. 1994, 33, 4016-4022. [CrossRef]

21. Bi, L.-H.; Wang, E.-B.; Peng, J.; Huang, R.-D.; Xu, L.; Hu, C.-W. Crystal Structure and Replacement Reaction of Coordinated Water Molecules of the Heteropoly Compounds of Sandwich-Type Tungstoarsenates. Inorg. Chem. 2000, 39, 671-679. [CrossRef] [PubMed]

22. Clemente-Juan, J.M.; Coronado, E.; Gaita-Ariño, A.; Giménez-Saiz, C.; Güdel, H.-U.; Sieber, A.; Bircher, R.; Mutka, H. Magnetic Polyoxometalates: Anisotropic Exchange Interactions in the $\mathrm{Co}_{3}{ }^{\mathrm{II}}$ Moiety of $\left[\left(\mathrm{NaOH}_{2}\right) \mathrm{Co}_{3}\left(\mathrm{H}_{2} \mathrm{O}\right)\left(\mathrm{P}_{2} \mathrm{~W}_{15} \mathrm{O}_{56}\right)_{2}\right]^{17-}$. Inorg. Chem. 2005, 44, 3389-3395. [CrossRef] [PubMed]

23. Ruhlmann, L.; Canny, J.; Contant, R.; Thouvenot, R. Di- and Tricobalt Dawson Sandwich Complexes: Synthesis, Spectroscopic Characterization and Electrochemical Behavior of $\mathrm{Na}_{18}\left[\left(\mathrm{NaOH}_{2}\right)_{2} \mathrm{Co}_{2}\left(\mathrm{P}_{2} \mathrm{~W}_{15} \mathrm{O}_{56}\right)_{2}\right]$ and $\mathrm{Na}_{17}\left[\left(\mathrm{NaOH}_{2}\right) \mathrm{Co}_{3}\left(\mathrm{H}_{2} \mathrm{O}\right)\left(\mathrm{P}_{2} \mathrm{~W}_{15} \mathrm{O}_{56}\right)_{2}\right.$ ]. Inorg. Chem. 2002, 41, 3811-3819. [CrossRef] [PubMed]

24. Anderson, T.M.; Fang, X.; Mbomekalle, I.M.; Keita, B.; Nadjo, L.; Hardcastle, K.I.; Farsidjani, A.; Hill, C.L. Structural and Electrochemical Studies of Dicupric Wells-Dawson Sandwich-Type Complexes. J. Clust. Sci. 2006, 17, 183-195. [CrossRef]

25. Ruhlmann, L.; Costa-Coquelard, C.; Canny, J.; Thouvenot, R. Mixed-Metal Dawson Sandwich Complexes: Synthesis, Spectroscopic Characterization and Electrochemical Behaviour of $\mathrm{Na}_{16}\left[\mathrm{M}^{\mathrm{II}} \mathrm{Co}_{3}\left(\mathrm{H}_{2} \mathrm{O}\right)_{2}\left(\mathrm{P}_{2} \mathrm{~W}_{15} \mathrm{O}_{56}\right)_{2}\right](\mathrm{M}=\mathrm{Mn}, \mathrm{Co}, \mathrm{Ni}, \mathrm{Zn}$ and $\mathrm{Cd})$. Eur. J. Inorg. Chem. 2007, 2007, 1493-1500. [CrossRef]

26. Zhang, X.; Chen, Q.; Duncan, D.C.; Campana, C.F.; Hill, C.L. Multiiron Polyoxoanions. Syntheses, Characterization, X-ray Crystal Structures and Catalysis of $\mathrm{H}_{2} \mathrm{O}_{2}$-Based Hydrocarbon Oxidations by $\left[\mathrm{Fe}^{\mathrm{III}}{ }_{4}\left(\mathrm{H}_{2} \mathrm{O}\right)_{2}\left(\mathrm{P}_{2} \mathrm{~W}_{15} \mathrm{O}_{56}\right)_{2}\right]^{12-}$. Inorg. Chem. 1997, 36, 4208-4215. [CrossRef]

27. Bassil, B.S.; Xiang, Y.; Haider, A.; Hurtado, J.; Novitchi, G.; Powell, A.K.; Bossoh, A.M.; Mbomekallé, I.M.; de Oliveira, P.; Kortz, U. Heptanickel(II) double-cubane core in wells-dawson heteropolytungstate, $\left[\mathrm{Ni}_{7}(\mathrm{OH})_{6}\left(\mathrm{H}_{2} \mathrm{O}\right)_{6}\left(\mathrm{P}_{2} \mathrm{~W}_{15} \mathrm{O}_{56}\right)_{2}\right]^{16-}$. Chem. Commun. 2016, 52, 2601-2604. [CrossRef]

28. Mbomekalle, I.M.; Keita, B.; Nadjo, L.; Neiwert, W.A.; Zhang, L.; Hardcastle, K.I.; Hill, C.L.; Anderson, T.M. Lacunary Wells-Dawson sandwich complexes-Synthesis, characterization and stability studies of multi-iron species. Eur. J. Inorg. Chem. 2003, 21, 3924-3928. [CrossRef]

29. Mbomekalle, I.M.; Cao, R.; Hardcastle, K.I.; Hill, C.L.; Ammam, M.; Keita, B.; Nadjo, L.; Anderson, T.M. Synthesis, structural characterization and electrocatalytic studies of $\alpha \beta \beta \alpha-\left(\mathrm{Zn}^{\mathrm{II}} \mathrm{OH}_{2}\right)_{2}\left(\mathrm{Fe}^{\mathrm{III}}\right)_{2}\left(\mathrm{X}_{2} \mathrm{~W}_{15} \mathrm{O}_{56}\right)_{2}{ }^{14-}$ (X = P or As). C. R. Chim. 2005, 8, 1077-1086. [CrossRef]

30. Ayingone Mezui, C.S.; de Oliveira, P.; Teillout, A.-L.; Marrot, J.; Berthet, P.; Lebrini, M.; Mbomekallé, I.M. Synthesis, Structure and Magnetic Electrochemical Properties of a Family of Tungstoarsenates Containing Just Co ${ }^{\mathrm{II}}$ Centers or Both Co ${ }^{\mathrm{II}}$ and Fe ${ }^{\mathrm{III}}$ Centers. Inorg. Chem. 2017, 56, 1999-2012. [CrossRef]

31. Floriant, D.; Charyle, S.A.M.; Pedro de, O.; Anne-Lucie, T.; Israel, M.M. Synthesis, Electrochemistry and Electro-Catalytic Properties of The Mixed Copper-Iron-Containing Sandwich-Type Polyoxometalates $\left[\left(\mathrm{Fe}^{\mathrm{III}} \mathrm{OH}\right)_{2} \mathrm{Cu}_{2}{ }_{2}\left(\mathrm{X}_{2} \mathrm{~W}_{15} \mathrm{O}_{56}\right)_{2}\right]^{14-}$ and $\left[\left(\mathrm{Cu}^{\mathrm{II}} \mathrm{OH}_{2}\right)_{2} \mathrm{Fe}^{\mathrm{III}}{ }_{2}\left(\mathrm{X}_{2} \mathrm{~W}_{15} \mathrm{O}_{56}\right)_{2}\right]^{14-}$ (with $\mathrm{X}=\mathrm{AsV}$ and PV). Curr. Inorg. Chem. Discontin. 2017, 7, 28-38.

32. Keggin, J.F. Structure of the Molecule of 12-Phosphotungstic Acid. Nature 1933, 131, 908. [CrossRef]

33. Keita, B.; Mialane, P.; Sécheresse, F.; de Oliveira, P.; Nadjo, L. Electrochemical generation of high-valent manganese catalysts in aqueous solutions from the sandwich-type polyoxoanion $\left[\left(\mathrm{Mn}^{\mathrm{III}}\left(\mathrm{H}_{2} \mathrm{O}\right)\right)_{3}\left(\mathrm{SbW}_{9} \mathrm{O}_{33}\right)_{2}\right]^{9-}$. Electrochem. Commun. 2007, 9, 164-172. [CrossRef]

34. Al-Oweini, R.; Bassil, B.S.; Palden, T.; Keita, B.; Lan, Y.; Powell, A.K.; Kortz, U. The manganese(III)-containing tungstophosphate $\left[\mathrm{Mn}_{3}^{\mathrm{III}}{ }_{3}\left(\mathrm{H}_{2} \mathrm{O}\right)_{5}\left(\mathrm{~A}-\alpha-\mathrm{PW}_{9} \mathrm{O}_{34}\right)_{2}\right]^{9-}$. Polyhedron 2013, 52, 461-466. [CrossRef]

35. Friedl, J.; Al-Oweini, R.; Herpich, M.; Keita, B.; Kortz, U.; Stimming, U. Electrochemical studies of tri-manganese substituted Keggin Polyoxoanions. Electrochim. Acta 2014, 141, 357-366. [CrossRef] 
36. Yu, L.; Ding, Y.; Zheng, M. Polyoxometalate-based manganese clusters as catalysts for efficient photocatalytic and electrochemical water oxidation. Appl. Catal. B Environ. 2017, 209, 45-52. [CrossRef]

37. Han, Q.; Ding, Y. Recent advances in the field of light-driven water oxidation catalyzed by transition-metal substituted polyoxometalates. Dalton Trans. 2018, 47, 8180-8188. [CrossRef] [PubMed]

38. Hill, C.L.; Brown, R.B. Sustained epoxidation of olefins by oxygen donors catalyzed by transition metal-substituted polyoxometalates, oxidatively resistant inorganic analogs of metalloporphyrins. J. Am. Chem. Soc. 1986, 108, 536-538. [CrossRef]

39. Lyon, D.K.; Miller, W.K.; Novet, T.; Domaille, P.J.; Evitt, E.; Johnson, D.C.; Finke, R.G. Highly oxidation resistant inorganic-porphyrin analog polyoxometalate oxidation catalysts. 1 . The synthesis and characterization of aqueous-soluble potassium salts of $\alpha_{2}-\mathrm{P}_{2} \mathrm{~W}_{17} \mathrm{O}_{61}\left(\mathrm{M}^{\mathrm{n}+} \cdot \mathrm{OH}_{2}\right)^{(\mathrm{n}-10)}$ and organic solvent soluble tetra- $n$-butylammonium salts of $\alpha_{2}-\mathrm{P}_{2} \mathrm{~W}_{17} \mathrm{O}_{61}\left(\mathrm{M}^{\mathrm{n}+} \cdot \mathrm{Br}\right)^{(\mathrm{n}-11)}\left(\mathrm{M}=\mathrm{Mn}^{3+}, \mathrm{Fe}^{3+}, \mathrm{Co}^{2+}, \mathrm{Ni}^{2+}, \mathrm{Cu}^{2+}\right)$. J. Am. Chem. Soc. 1991, 113, 7209-7221.

40. Mansuy, D.; Bartoli, J.F.; Battioni, P.; Lyon, D.K.; Finke, R.G. Highly oxidation resistant inorganic-porphyrin analog polyoxometalate oxidation catalysts. 2. Catalysis of olefin epoxidation and aliphatic and aromatic hydroxylations starting from $\alpha_{2}-\mathrm{P}_{2} \mathrm{~W}_{17} \mathrm{O}_{61}\left(\mathrm{M}^{n+} \cdot \mathrm{Br}\right)^{(n-11)}\left(\mathrm{M}^{n+}=\mathrm{Mn}^{3+}, \mathrm{Fe}^{3+}, \mathrm{Co}^{2+}, \mathrm{Ni}^{2+}, \mathrm{Cu}^{2+}\right)$, including quantitative comparisons to metalloporphyrin catalysts. J. Am. Chem. Soc. 1991, 113, 7222-7226.

41. Neumann, R.; Gara, M. Highly Active Manganese-Containing Polyoxometalate as Catalyst for Epoxidation of Alkenes with Hydrogen Peroxide. J. Am. Chem. Soc. 1994, 116, 5509-5510. [CrossRef]

42. Hill, C.L.; Prosser-McCartha, C.M. Homogeneous catalysis by transition metal oxygen anion clusters. Coord. Chem. Rev. 1995, 143, 407-455. [CrossRef]

43. Neumann, R.; Gara, M. The Manganese-Containing Polyoxometalate, $\left[\mathrm{WZnMn}_{2}\left(\mathrm{ZnW}_{9} \mathrm{O}_{34}\right)_{2}\right]^{12-}$, as a Remarkably Effective Catalyst for Hydrogen Peroxide Mediated Oxidations. J. Am. Chem. Soc. 1995, 117, 5066-5074. [CrossRef]

44. Neumann, R.; Juwiler, D. Oxidations with hydrogen peroxide catalysed by the $\left[\mathrm{WZnMn}{ }^{(\mathrm{II})}{ }_{2}\left(\mathrm{ZnW}_{9} \mathrm{O}_{34}\right)_{2}\right]^{12-}$ polyoxometalate. Tetrahedron 1996, 52, 8781-8788. [CrossRef]

45. Bösing, M.; Nöh, A.; Loose, I.; Krebs, B. Highly Efficient Catalysts in Directed Oxygen-Transfer Processes: Synthesis, Structures of Novel Manganese-Containing Heteropolyanions and Applications in Regioselective Epoxidation of Dienes with Hydrogen Peroxide. J. Am. Chem. Soc. 1998, 120, 7252-7259. [CrossRef]

46. Neumann, R.; Khenkin, A.M. Alkane oxidation with manganese substituted polyoxometalates in aqueous media with ozone and the intermediacy of manganese ozonide species. Chem. Commun. 1998, 1967-1968. [CrossRef]

47. Bösing, M.; Krebs, B.; Nestler, B.; Seebach, M.; Reinhardt, G.; Wohlers, M.; Dingerdissen, U. Low-temperature bleaching with manganese-containing heteropolytungstates. Appl. Catal. A Gen. 1999, 184, 273-278. [CrossRef]

48. Ben-Daniel, R.; Weiner, L.; Neumann, R. Activation of Nitrous Oxide and Selective Epoxidation of Alkenes

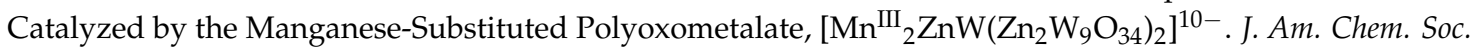
2002, 124, 8788-8789. [CrossRef] [PubMed]

49. Gamelas, J.A.F.; Gaspar, A.R.; Evtuguin, D.V.; Pascoal Neto, C. Transition metal substituted polyoxotungstates for the oxygen delignification of kraft pulp. Appl. Catal. A Gen. 2005, 295, 134-141. [CrossRef]

50. Khenkin, A.M.; Kumar, D.; Shaik, S.; Neumann, R. Characterization of Manganese(V)-Oxo Polyoxometalate Intermediates and Their Properties in Oxygen-Transfer Reactions. J. Am. Chem. Soc. 2006, 128, 15451-15460. [CrossRef] [PubMed]

51. Keita, B.; Nadjo, L. Electrochemistry of Isopoly and Heteropoly Oxometalates. In Encyclopedia of Electrochemistry; Wiley-VCH Verlag GmbH \& Co. KGaA: Weinheim, Germany, 2007.

52. Ruhlmann, L.; Costa-Coquelard, C.; Canny, J.; Thouvenot, R. Electrochemical and electrocatalytical investigations on the trimanganese sandwich complex $\left[\mathrm{NaMn}_{3}\left(\mathrm{H}_{2} \mathrm{O}\right)_{2}\left(\mathrm{P}_{2} \mathrm{~W}_{15} \mathrm{O}_{56}\right)_{2}\right]^{17-}$. J. Electroanal. Chem. 2007, 603, 260-268. [CrossRef]

53. Ammam, M.; Keita, B.; Nadjo, L.; Mbomekalle, I.-M.; Ritorto, M.D.; Anderson, T.M.; Neiwert, W.A.; Hill, C.L.; Fransaer, J. Cyclic Voltammetry Study of the Mn-Substituted Polyoxoanions $\left[\mathrm{Mn}_{4}{ }_{4}\left(\mathrm{H}_{2} \mathrm{O}\right)_{2}\left(\mathrm{H}_{4} \mathrm{AsW}_{15} \mathrm{O}_{56}\right)_{2}\right]^{18-}$ and $\left[\left(\left(\mathrm{Mn}^{\mathrm{II}} \mathrm{OH}_{2}\right) \mathrm{Mn}_{2}{ }_{2} \mathrm{PW}_{9} \mathrm{O}_{34}\right)_{2}\left(\mathrm{PW}_{6} \mathrm{O}_{26}\right)\right]^{17-}: \quad$ Electrodeposition of Manganese Oxides Electrocatalysts for Dioxygen Reduction. Electroanalysis 2011, 23, 1427-1434. [CrossRef] 
54. Folkman, S.J.; Finke, R.G. Electrochemical Water Oxidation Catalysis Beginning with Co(II) Polyoxometalates: The Case of the Precatalyst $\mathrm{Co}_{4} \mathrm{~V}_{2} \mathrm{~W}_{18} \mathrm{O}_{68}{ }^{10-}$. ACS Catal. 2017, 7, 7-16. [CrossRef]

55. Folkman, S.J.; Soriano-Lopez, J.; Galán-Mascarós, J.R.; Finke, R.G. Electrochemically Driven Water-Oxidation Catalysis Beginning with Six Exemplary Cobalt Polyoxometalates: Is It Molecular, Homogeneous Catalysis or Electrode-Bound, Heterogeneous CoOx Catalysis? J. Am. Chem. Soc. 2018, 140, 12040-12055. [CrossRef] [PubMed]

56. Stracke, J.J.; Finke, R.G. Electrocatalytic Water Oxidation Beginning with the Cobalt Polyoxometalate $\left[\mathrm{Co}_{4}\left(\mathrm{H}_{2} \mathrm{O}\right)_{2}\left(\mathrm{PW}_{9} \mathrm{O}_{34}\right)_{2}\right]^{10-}$ : Identification of Heterogeneous $\mathrm{CoOx}$ as the Dominant Catalyst. J. Am. Chem. Soc. 2011, 133, 14872-14875. [CrossRef] [PubMed]

57. Stracke, J.J.; Finke, R.G. Water Oxidation Catalysis Beginning with $2.5 \mu \mathrm{M}\left[\mathrm{Co}_{4}\left(\mathrm{H}_{2} \mathrm{O}\right)_{2}\left(\mathrm{PW}_{9} \mathrm{O}_{34}\right)_{2}\right]^{10-}$ : Investigation of the True Electrochemically Driven Catalyst at $\geq 600 \mathrm{mV}$ Overpotential at a Glassy Carbon Electrode. ACS Catal. 2013, 3, 1209-1219. [CrossRef]

58. Stracke, J.J.; Finke, R.G. Distinguishing Homogeneous from Heterogeneous Water Oxidation Catalysis when Beginning with Polyoxometalates. ACS Catal. 2014, 4, 909-933. [CrossRef]

59. Stracke, J.J.; Finke, R.G. Water Oxidation Catalysis Beginning with $\mathrm{Co}_{4}\left(\mathrm{H}_{2} \mathrm{O}\right)_{2}\left(\mathrm{PW}_{9} \mathrm{O}_{34}\right)_{2}{ }^{10-}$ When Driven by the Chemical Oxidant Ruthenium(III)tris(2,2'-bipyridine): Stoichiometry, Kinetic and Mechanistic Studies en Route to Identifying the True Catalyst. ACS Catal. 2014, 4, 79-89. [CrossRef]

60. Barats-Damatov, D.; Shimon, L.J.W.; Weiner, L.; Schreiber, R.E.; Jiménez-Lozano, P.; Poblet, J.M.; de Graaf, C.; Neumann, R. Dicobalt- $\mu$-oxo Polyoxometalate Compound, $\left[\left(\alpha_{2}-\mathrm{P}_{2} \mathrm{~W}_{17} \mathrm{O}_{61} \mathrm{Co}\right)_{2} \mathrm{O}\right]^{14-}$ : A Potent Species for Water Oxidation, C-H Bond Activation and Oxygen Transfer. Inorg. Chem. 2014, 53, 1779-1787. [CrossRef]

61. Evangelisti, F.; Car, P.-E.; Blacque, O.; Patzke, G.R. Photocatalytic water oxidation with cobalt-containing tungstobismutates: Tuning the metal core. Catal. Sci. Technol. 2013, 3, 3117-3129. [CrossRef]

62. Lv, H.; Song, J.; Geletii, Y.V.; Vickers, J.W.; Sumliner, J.M.; Musaev, D.G.; Kögerler, P.; Zhuk, P.F.; Bacsa, J.; Zhu, G.; et al. An Exceptionally Fast Homogeneous Carbon-Free Cobalt-Based Water Oxidation Catalyst. J. Am. Chem. Soc. 2014, 136, 9268-9271. [CrossRef]

63. Vickers, J.W.; Lv, H.; Sumliner, J.M.; Zhu, G.; Luo, Z.; Musaev, D.G.; Geletii, Y.V.; Hill, C.L. Differentiating Homogeneous and Heterogeneous Water Oxidation Catalysis: Confirmation that $\left[\mathrm{Co}_{4}\left(\mathrm{H}_{2} \mathrm{O}\right)_{2}\left(\alpha-\mathrm{PW}_{9} \mathrm{O}_{34}\right)_{2}\right]^{10-}$ Is a Molecular Water Oxidation Catalyst. J. Am. Chem. Soc. 2013, 135, 14110-14118. [CrossRef]

64. Zhu, G.; Geletii, Y.V.; Kögerler, P.; Schilder, H.; Song, J.; Lense, S.; Zhao, C.; Hardcastle, K.I.; Musaev, D.G.; Hill, C.L. Water oxidation catalyzed by a new tetracobalt-substituted polyoxometalate complex: $\left[\left\{\mathrm{Co}_{4}(\mu-\mathrm{OH})\left(\mathrm{H}_{2} \mathrm{O}\right)_{3}\right\}\left(\mathrm{Si}_{2} \mathrm{~W}_{19} \mathrm{O}_{70}\right)\right]^{11-}$. Dalton Trans. 2012, 41, 2084-2090. [CrossRef] [PubMed]

65. Soriano-López, J.; Goberna-Ferrón, S.; Vigara, L.; Carbó, J.J.; Poblet, J.M.; Galán-Mascarós, J.R. Cobalt Polyoxometalates as Heterogeneous Water Oxidation Catalysts. Inorg. Chem. 2013, 52, 4753-4755. [CrossRef] [PubMed]

66. Li, J.; Wang, J.; Zhang, L.; Sang, X.; You, W. Determination of the stability constant of cobalt-substituted mono-lacunary Keggin-type polyoxometalate and its electrocatalytic water oxidation performance. J. Coord. Chem. 2017, 70, 2950-2957. [CrossRef]

67. Sun, C.-Y.; Liu, S.-X.; Xie, L.-H.; Wang, C.-L.; Gao, B.; Zhang, C.-D.; Su, Z.-M. Synthesis and characterization of one- to three-dimensional compounds composed of paradodecatungstate-B cluster and transition metals as linkers. J. Solid State Chem. 2006, 179, 2093-2100. [CrossRef]

68. Gimenez-Saiz, C.; Galan-Mascaros, J.R.; Triki, S.; Coronado, E.; Ouahab, L. $\left[\left(\mathrm{Co}\left(\mathrm{H}_{2} \mathrm{O}\right)_{4}\right)_{2}\left(\mathrm{H}_{2} \mathrm{~W}_{12} \mathrm{O}_{42}\right)\right]_{n}{ }^{6 n-}$ : A Novel Chainlike Heteropolyanion Formed by Paradodecatungstate and Cobalt(II) Ions. Inorg. Chem. 1995, 34, 524-526. [CrossRef]

69. Evans, H.T.; Rollins, O.W. Sodium paradodecatungstate 20-hydrate. Acta Crystallogr. Sect. B 1976, 32, 1565-1567. [CrossRef]

70. Yuan, L.; Qin, C.; Wang, X.; Wang, E.; Li, Y. A new series of polyoxometalate compounds built up of paradodecatungstate anions and transition metal/alkaline-earth metal cations. Solid State Sci. 2008, 10, 967-975. [CrossRef]

71. Yang, W.-B.; Lu, C.-Z.; Lin, X.; Zhuang, H.-H. Syntheses, Structures and Magnetic Properties of Three New Extended Iron-containing Heteropolytungstates. Z. Anorg. Allg. Chem. 2003, 629, 2046-2052. [CrossRef] 
72. Xu, X.; Luo, F.; Luo, W.; Chen, J. Synthesis and Crystal Structure of a New 3D Copper B-Paradodecatungstate Compound: $\left[\mathrm{Na}_{2}\left(\mathrm{H}_{2} \mathrm{O}\right)_{8}\right]\left[\mathrm{Na}_{8}\left(\mathrm{H}_{2} \mathrm{O}\right)_{20}\right]\left[\mathrm{Cu}(\mathrm{en})_{2}\right]\left[\mathrm{W}_{12} \mathrm{O}_{42}\right] \cdot 3 \mathrm{H}_{2} \mathrm{O}$. Zeitschrift für Naturforschung B 2009, 64, 269. [CrossRef]

73. Wu, L.; Yang, W.; Dong, X.; Yu, C.; Liu, B.; Yan, Y.; Hu, H.; Xue, G. A pure inorganic 2-D framework based on paradodecatungstate and $\mathrm{Mn}^{2+}$ ions: Syntheses, structure and properties. J. Coord. Chem. 2015, 68, 2324-2333. [CrossRef]

74. Wasfi, S.H.; Rheingold, A.L.; Kokoszka, G.F.; Goldstein, A.S. Preparation, structure and magnetic properties of $\mathrm{Na}_{10} \mathrm{Fe}_{4} \mathrm{Cu}_{2} \mathrm{~W}_{18} \mathrm{O}_{70} \mathrm{H}_{6} \cdot 29 \mathrm{H}_{2} \mathrm{O}$, containing the double Keggin anion $\left[\mathrm{Fe}_{4} \mathrm{Cu}_{2} \mathrm{~W}_{18} \mathrm{O}_{70} \mathrm{H}_{6}\right]^{10-}$. Inorg. Chem. 1987, 26, 2934-2939. [CrossRef]

75. Biesinger, M.C.; Payne, B.P.; Grosvenor, A.P.; Lau, L.W.M.; Gerson, A.R.; Smart, R.S.C. Resolving surface chemical states in XPS analysis of first row transition metals, oxides and hydroxides: $\mathrm{Cr}, \mathrm{Mn}, \mathrm{Fe}, \mathrm{Co}$ and $\mathrm{Ni}$. Appl. Surf. Sci. 2011, 257, 2717-2730. [CrossRef]

76. Laha, S.; Sharma, R.; Bhat, S.V.; Reddy, M.L.P.; Gopalakrishnan, J.; Natarajan, S. $\mathrm{Ba}_{3}\left(\mathrm{P}_{1-x} \mathrm{Mn}_{x} \mathrm{O}_{4}\right)_{2}$ : Blue/green inorganic materials based on tetrahedral Mn(V). Bull. Mater. Sci. 2011, 34, 1257-1262. [CrossRef]

77. Medina, E.A.; Li, J.; Stalick, J.K.; Subramanian, M.A. Intense turquoise colors of apatite-type compounds with $\mathrm{Mn}^{5+}$ in tetrahedral coordination. Solid State Sci. 2016, 52, 97-105. [CrossRef]

78. Drewes, D.; Piepenbrink, M.; Krebs, B. The First Structurally Characterized Mn(III) Substituted Sandwich-type Polyoxotungstates. J. Clust. Sci. 2006, 17, 361-374. [CrossRef]

79. Sheldrick, G.M. SADABS, Program for Scaling and Correction of Area Detector Data; University of Göttingen: Göttingen, Germany, 1997.

80. Blessing, R. An empirical correction for absorption anisotropy. Acta Crystallogr. Sect. A 1995, 51, 33-38. [CrossRef]

81. Sheldrick, G.M. SHELX-TL, Software Package for the Crystal Structure Determination, Version 5.03; Siemens Analytical X-ray Instrument Division: Madison, WI, USA, 1994.

82. Vila, N.; Aparicio, P.A.; Secheresse, F.; Poblet, J.M.; Lopez, X.; Mbomekalle, I.M. Electrochemical behavior of $\left.\alpha 1 / \alpha 2-\left[\mathrm{Fe}\left(\mathrm{H}_{2} \mathrm{O}\right) \mathrm{P}_{2} \mathrm{~W}_{17} \mathrm{O}_{61}\right]{ }^{7-}\right)$ isomers in solution: Experimental and DFT studies. Inorg. Chem. 2012, 51, C-38. [CrossRef] [PubMed] 